Article

\title{
Impact of Heavy Metals on Community Farming Activities in the Central Peruvian Andes
}

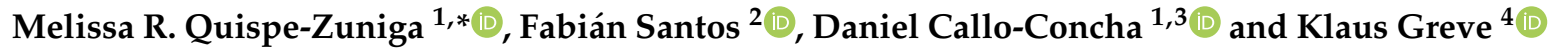 \\ 1 Center for Development Research, University of Bonn, Genscherallee 3, 53113 Bonn, Germany; \\ d.callo-concha@uni-bonn.de \\ 2 Centro para la Investigación del Territorio y Hábitat Sostenible, Universidad Tecnológica Indoamérica, \\ 170103 Quito, Ecuador; ernestosantos@uti.edu.ec \\ 3 Institute for Environmental Sciences (iES), University of Koblenz-Landau, Forstraße 7, \\ 76829 Landau, Germany \\ 4 Department of Geography, University of Bonn, Meckenheimer Allee 166, 53115 Bonn, Germany; \\ klaus.greve@uni-bonn.de \\ * Correspondence: melissaquispe@daad-alumni.de; Tel.: +49-228-73-4976
}

Received: 30 July 2019; Accepted: 18 October 2019; Published: 22 October 2019

check for updates

\begin{abstract}
The high mining potential of the Peruvian Andes has promoted booming foreign investments. The mining activity takes place on campesino community lands and headwaters. Once the government awards a mining concession, mining companies must regularly negotiate land rent with communities over the whole duration of the mining operation, often leading to disagreements. Our research objective is to identify the mining impacts on the farming activities of campesino communities in the Junin region, central Peruvian Andes. Using a mixed-methods approach involving in-depth interviews, water and soil analysis, land-cover classification and participatory mapping, we analyzed the mining-community agreements and the mining impacts on the farming lands. We arrived at two primary conclusions. First, mining activities in terms of heavy metal concentrations impact on farming lands, although the contribution of previous and concurrent activities cannot be distinguished. Second, the diverging and short-termed interests of the involved parties which circumscribe the agreements may potentially lead to conflicts.
\end{abstract}

Keywords: water and soil quality; community lands; mining operations; land-use conflicts

\section{Introduction}

A recent boom in mining exploitation has extended along the Andes, overlapping with community lands and water bodies [1]. It is estimated that the livelihoods of 40 million people depend on these Andean ecosystems [2,3]. In the case of Peru, most of the Andes are occupied by campesino communities. Legally, a campesino community is a set of neighboring households that share the collective ownership of a determined area [4-6] and are economically dependent primarily on agricultural and livestock-related activities [7-10].

Recently, land-use conflicts have emerged between campesino communities and mining operations [11-13]. These mainly occur due to the underrepresentation of campesino communities in the decision-making processes $[1,13]$, location of the mining operations and subsequent endangerment of water quality, and inefficient use of water [1,12,14-17].

Nevertheless, the number of mining projects has increased in Peru due to legislation that favors investments [12]. The General Mining Law of 1992 set a roadmap for establishing mining operations that mainly consider the "exploration" and "exploitation" phases [18]. Generally, the operation requires the permission of the Ministry of Energy and Mining and the campesino community/communities that 
own the land $[17,19]$. Based on the canon minero, 50\% of the taxes from the mining sector is distributed among the affected subnational governments (i.e., district and province) [20-23]. The subnational governments directly affected by mining may receive up to $70 \%$ of this tax $[11,18,24]$, while campesino communities are excluded from receiving it directly. As a result, the communities tend to negotiate compensations separately with the mining companies. Both canon minero and compensations are aimed at reducing land-use conflicts. Despite this, conflicts increased (2005-2011), reduced in 2012 and have remained constant (ca. 162 yearly conflicts) since then [19,25-37]. In 2017, Peru allocated 16 million ha for mining concessions [38], although not all of these became viable mines. The most common mining practice in Peru is open-pit mining, as this model is preferred for exploiting metal deposits. There are 36 open-pit mines throughout the country [39]. The environmental impacts of open-pit mining mainly relate to water infiltration and supply to rivers [12,40-42], which impact the socio-economic situation of local households [1,43-45].

Most studies have split these biophysical and socio-economic aspects rather than integrating them [43-46]. Therefore, an interdisciplinary approach [47] is suggested to broaden the understanding of the impacts of mining from different perspectives. In this sense, the overarching objective of this study is to identify the mining impacts on the farming activities of campesino communities in the Junin region. Therefore, we first analyzed the agreements between mining companies and communities via in-depth interviews with stakeholders. Then, we evaluated the influence by open-pit mining sites on the water and soil quality and assessed the effects on farming lands. The following research questions guide our work: How are the agreements between mining companies and communities established? Do mining activities in terms of heavy metal concentrations impact on farming lands?

\section{Materials and Methods}

Under the interdisciplinary approach, this investigation applied mixed methods $[48,49]$ including in-depth interviews to analyze the negotiation process between campesino communities and mining companies, laboratory analyses to measure heavy metal concentrations in streams and farmland soils around the mines, and participatory mapping and GIS-based land-cover classification to assess the perspectives of the community members and effects on their livelihoods. For the water and soil analyses, we used inductively coupled plasma-optical emission spectrometry (ICP-OES) [50], and for the mapping ArcGIS [51] and R programming language [52-54] (Figure 1).

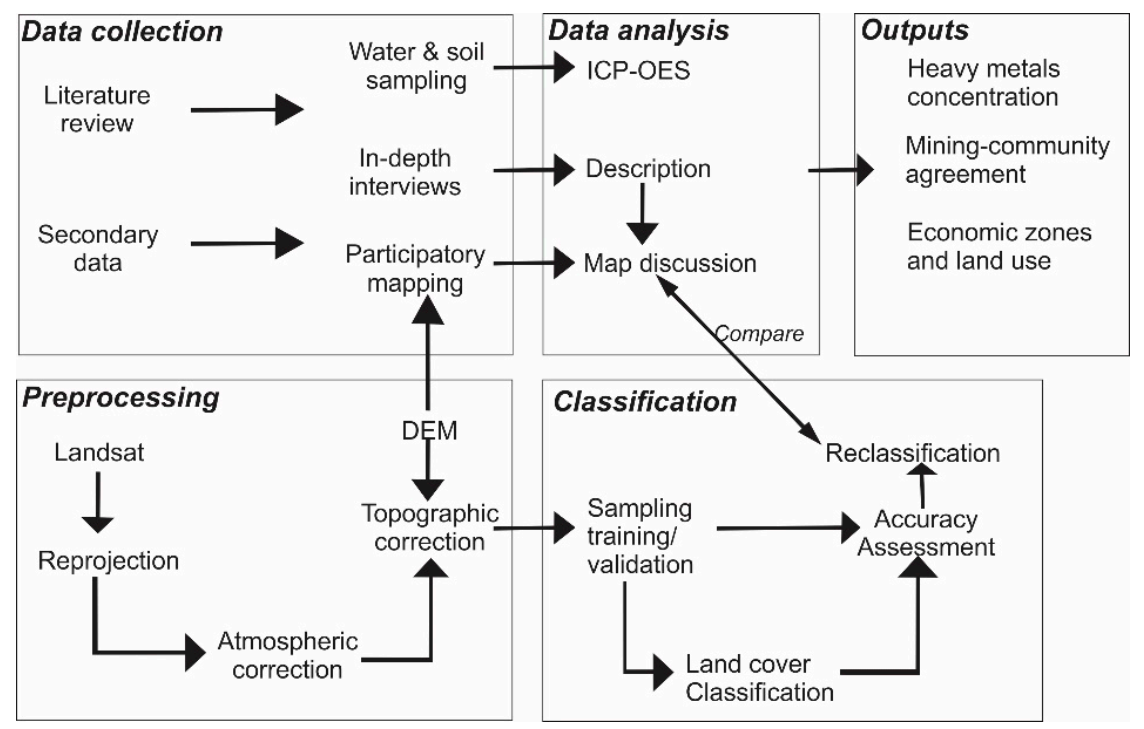

Figure 1. Overview of the research methodology (based on $[50,55,56])$. 


\subsection{Research Site}

The Junin region $\left(\mathrm{S}^{\circ} 1^{\circ} 29^{\prime}-\mathrm{W} 74^{\circ} 59^{\prime}\right)$ within the Mantaro watershed hosts a large number of mining companies, is of great importance for agricultural production, and encompasses 389 campesino communities [57-60]. Our study area includes the sub-basins Cunas and Aimaraes of the watershed [61-63] within which are located 14 campesino communities and three mining sites. The Azulcocha mine is in the Cunas sub-basin, while the Corihuarmi and Huacravilca mines are in the Aimaraes sub-basin (Figure 2). The Azulcocha mine is situated on glacial and glaciofluvial bedrocks in an irregular gorge with different landforms [63]. The mine currently covers 8600 ha at $4400 \mathrm{~m}$ above sea level (MASL) for zinc production, and a concentrator plant with 500 ton/day processing capacity $[64,65]$. The Corihuarmi mine, located in an epithermal gold-silver belt, is an open-pit mine covering 10,168 ha at ca. 5000 MASL and exploits gold [66-69]. The Huacravilca mine covers 2000 ha for exploration at 4700 MASL over fluvial and glaciofluvial deposits and six sedimentary units [70-72].

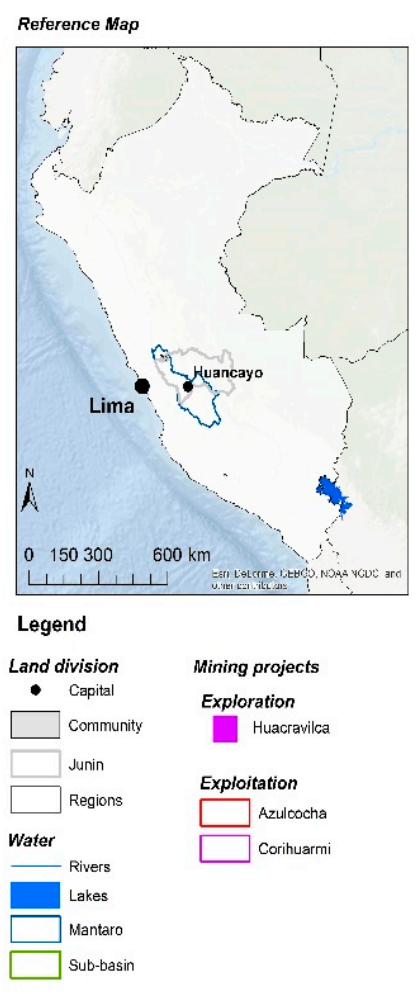

(a)

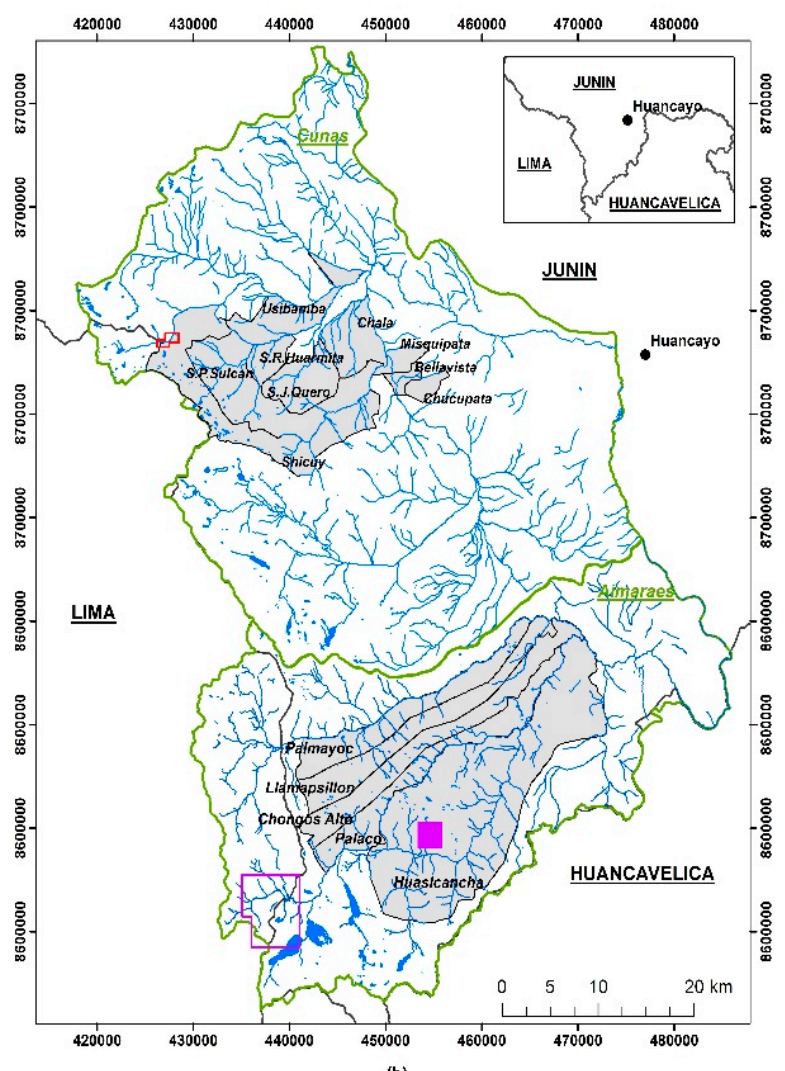

(b)

Figure 2. Research area in (a) Junin region and (b) location of mining operations and campesino communities in Aimaraes and Cunas sub-basins (based on governmental data and INGEMMET [73]).

After sub-national governments and community authorities had authorized our study, 14 out of 18 communities agreed to participate, i.e., nine from the Cunas sub-basin and five from the Aimaraes sub-basin. As not all communities are affected by mining operations in the same way, the considered campesino communities were divided into mining-affected and not mining-affected communities (Figure 2; Table 1). 
Table 1. Mining operations with stage of use and assessed campesino communities with the number of active members in parentheses.

\begin{tabular}{ccc}
\hline & Cunas Sub-Basin & Aimaraes Sub-Basin \\
\hline Mining Operation & Azulcocha (exploitation: Zn) & $\begin{array}{c}\text { Huacravilca (exploration: Ag) } \\
\text { Corihuarmi (exploitation: Au) }\end{array}$ \\
\hline Mining-Affected Communities & San Pedro de Sulcan (25) & Huasicancha (251) \\
& Usibamba (238) & Chongos Alto (108) \\
& Shicuy (75) & Palmayoc (22) \\
& & Plamapo (23) \\
Not Mining-Affected & Chala (72) & \\
Community & Santa Rosa de Huarmita (23) & \\
& San José de Quero (30) & No control community \\
& Bellavista (50) & \\
& Misquipata (30) & \\
\hline
\end{tabular}

\subsection{Interviews with Stakeholders}

To understand the negotiation dynamics between mining operations and campesino communities, in-depth interviews with community authorities and representatives of the mining operations were carried out (Appendix A). In total, we interviewed authorities from each mining-affected community and five representatives of four mining companies. In addition to the mining companies operating in our study area (Table 1), a fourth mine-Volcan mining company-was included considering its long history (ca. 75 years) in the Junin region and its track record of negotiations with the communities. The identity of all stakeholders was anonymized given the sensitive character of the revealed information. All in-depth interviews were carried out in Spanish.

\subsection{Water and Soil Sampling}

To explore the historical presence of heavy metals in the surroundings of the sample points (Table 2), we used the regional geology and geochemistry data of the Geological, Mining and Metallurgical Institute (INGEMMET) [73]. Also, we used the assessments of the Agency for Environmental Assessment and Enforcement (OEFA), which found concentrations of heavy metals that were higher than the threshold allowed by the Environmental Quality Standards (EQS) [74-76] (Appendix B). In this study, 12 sample points were selected along the rivers Pucara (Cunas sub-basin) and Aimaraes. At each sample point, we took two samples, i.e., 24 water samples, during the dry season (October-November) of 2016.

Azulcocha and Corihuarmi are located at the headwaters of the Aimaraes and Cunas sub-basins. In each sub-basin, four case sample points and two control sample points were selected, i.e., a total of eight cases and four control samples. Case sample points were taken upstream (approx. 50 to $100 \mathrm{~m}$ ) and downstream (approx. 100 to $500 \mathrm{~m}$ ) of the mining sites and campesino communities (Figure 3). Water sampling followed the national protocol of Peru's National Authority of Water [77]. The 24 samples were sent to the Corrosion and Protection Institute of Pontifical Catholic University of Peru (PUCP) to determine total heavy metal concentrations through inductively coupled plasma-optical emission spectrometry (ICP-OES) according to the EPA (United States Environmental Protection Agency) method 200.7-Rev. 4.4. [50]. 

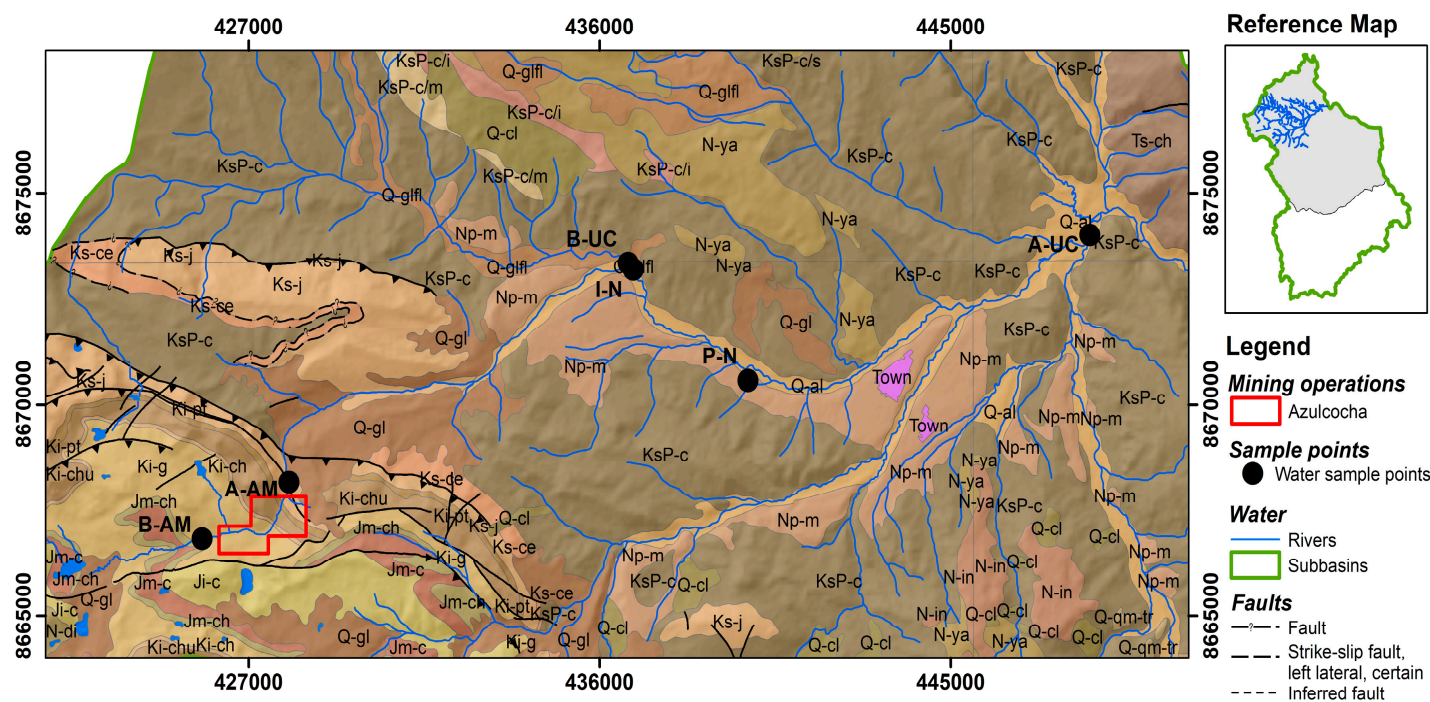

Legend

Mining operations

Azulcocha

¿ Sample points

Water sample points

Water

${ }_{\square}^{\text {Water }}$ Rubbas

Subbasins

@ - - Strike-slip fault,

left lateral, certain
-.-- Inferred fault

ـ. Thrust fault

$\Longrightarrow$ Fault, certain

(a)
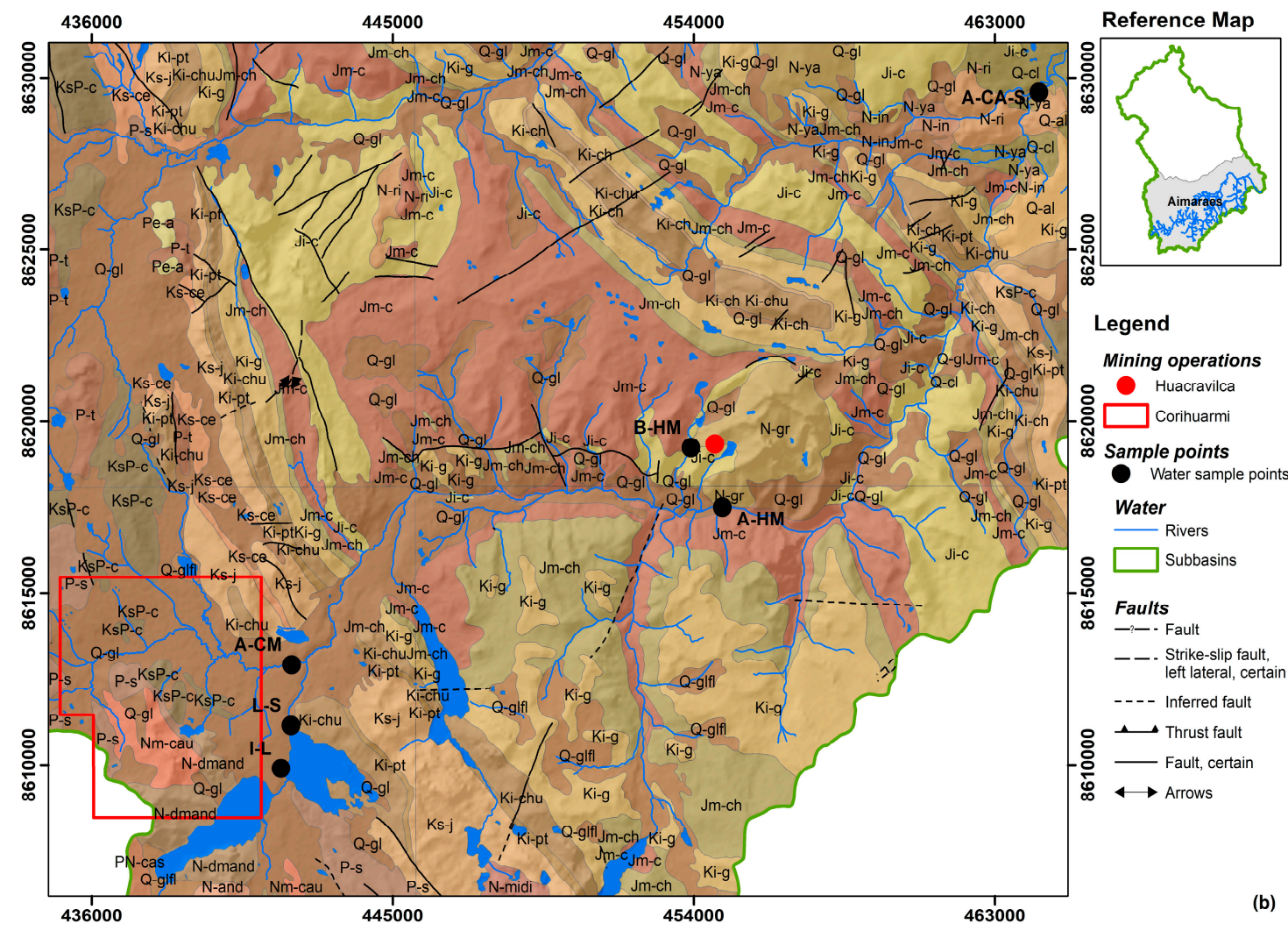

Figure 3. Water sample points and geology in (a) Cunas and (b) Aimaraes sub-basins; based on Geological, Mining and Metallurgical Institute (INGEMMET) [73]. 
Table 2. Geological characteristics and natural heavy metals (HM) presence in water sample points and their surroundings.

\begin{tabular}{|c|c|c|c|c|c|}
\hline \multirow{2}{*}{ Sub-Basin } & \multirow{2}{*}{ Sample } & \multicolumn{2}{|c|}{ Lithology and Geochemistry } & \multicolumn{2}{|c|}{ Surroundings of Sample Points } \\
\hline & & Geological unit & HM & Geological unit & HM \\
\hline \multirow{6}{*}{ Cunas } & B-AM (upstream Azulcocha) & $\begin{array}{l}\text { Goyllarisquizga } \\
\text { Group (Ki-g) }\end{array}$ & & $\begin{array}{l}\text { Chunumayo F. (Jm-ch) } \\
\text { Cercapuquio F. (Jm-c) }\end{array}$ & \\
\hline & $\begin{array}{l}\text { A-AM (Downstream } \\
\text { Azulcocha) }\end{array}$ & Jumasha F. (Ks-j) & & $\begin{array}{l}\text { Pariatambo F. (Ki-pt) } \\
\text { Glacial D. (Q-gl) }\end{array}$ & \\
\hline & $\begin{array}{l}\text { B-UC (Control 1, upstream } \\
\text { Usibamba) }\end{array}$ & $\begin{array}{l}\text { Glacial, fluvial D. } \\
\text { (Q-glfl) }\end{array}$ & $\mathrm{Cr}$ & $\begin{array}{l}\text { Casapalca F. (KsP-c) } \\
\text { Alluvial D. (Q-al) }\end{array}$ & \\
\hline & A-UC (After Usibamba) & Alluvial D. (Q-al) & $\mathrm{Cr}, \mathrm{As}, \mathrm{Cd}$ & Casapalca F. (KsP-c) & $\mathrm{Cr}$ \\
\hline & I-N (Confluence of rivers) & $\begin{array}{l}\text { Glacial, fluvial D. } \\
\text { (Q-glfl) }\end{array}$ & & $\begin{array}{l}\text { Alluvial D. (Q-al) } \\
\text { Casapalca F. (KsP-c) }\end{array}$ & \\
\hline & PN (Control 2) & Mataula F. (Np-m) & $\mathrm{Cr}$ & $\begin{array}{l}\text { Alluvial D. (Q-al) } \\
\text { Casapalca F. (KsP-c) }\end{array}$ & \\
\hline \multirow{6}{*}{ Aimaraes } & I-L (Control 1) & Glacial D. (Q-gl) & & $\begin{array}{l}\text { Domo andesítico } \\
\text { (N/dmand) }\end{array}$ & \\
\hline & L-S (Control 2) & Glacial D. (Q-gl) & & $\begin{array}{l}\text { Chúlec F. (Ki-chu) } \\
\text { Casapalca F. (KsP-c) }\end{array}$ & \\
\hline & $\begin{array}{l}\text { A-CM (Downstream } \\
\text { Corihuarmi) }\end{array}$ & Glacial D. (Q-gl) & $\mathrm{Hg}, \mathrm{Cr}, \mathrm{As}$ & $\begin{array}{l}\text { Jumasha F. (Ks-j) } \\
\text { Chúlec F. (Ki-chu) }\end{array}$ & \\
\hline & $\begin{array}{l}\text { B-HM (upstream } \\
\text { Huacravilca) }\end{array}$ & $\begin{array}{l}\text { Condorsinga } \mathrm{F} . \\
(\mathrm{Ji}-\mathrm{c})\end{array}$ & & $\begin{array}{l}\text { Cercapuquio F. (Jm-c) } \\
\text { Granite (N-gr) }\end{array}$ & \\
\hline & $\begin{array}{l}\text { A-HM (Downstream } \\
\text { Huacravilca) }\end{array}$ & Glacial D. (Q-gl) & $\mathrm{Hg}, \mathrm{Cr}$, As & $\begin{array}{c}\text { Granite (N-gr) } \\
\text { Cercapuquio F. (Jm-c) }\end{array}$ & \\
\hline & $\begin{array}{c}\text { A-CA-S (Downstream } \\
\text { Huasicancha disputed area) }\end{array}$ & Colluvial D. (Q-cl) & $\mathrm{Cr}, \mathrm{As}, \mathrm{Pb}, \mathrm{Cd}$ & $\begin{array}{l}\text { Yanacancha F. (N-ya) } \\
\text { Rhyolite (Nri) }\end{array}$ & \\
\hline
\end{tabular}

D.: Deposit, F.: Formation; based on $[73,78,79]$.

Regarding the presence of heavy metals, INGEMMET identified contents of mercury ( $\mathrm{Hg})$, chromium $(\mathrm{Cr})$ and/or arsenic (As) in the Aimaraes glacial deposits and contents of $\mathrm{Cr}$, As, lead $(\mathrm{Pb})$ and cadmium (Cd) in colluvial deposits [73]. In the Cunas sub-basin, $\mathrm{Cr}$ contents were found in alluvial and glacial-fluvial deposits and in the Mataula Formation (This formation is characterized by its lacustrine layers, sands and sandstones and fluvial conglomerates $[63,78]$ ) and Casapalca Formation (This formation is older than the Mataula formation and is characterized by shales, siltstones, sandstones and hematite-based conglomerates [63,78]). High contents of As and Cd in two Cunas alluvial deposits had also been previously identified [73]. The presence of heavy metals in the samples is summarized in Table 2.

Regarding soils, the sample points correspond to natural pastures used for grazing by the communities. It was verified that in each sample site there was no evidence of recent landslides that would alter results. In each sub-basin, the sample points were located $12 \mathrm{~km}$ and $24 \mathrm{~km}$ away from the mining exploitation sites near the aforementioned river courses (downstream). Control sample points were taken in non-mining areas that have the same dominant geological type. Due to the farming nature of lands and the Peruvian protocol for soil sampling, two samples were taken at 30 and $60 \mathrm{~cm}$ depth per sample point $[80,81]$. At each sample point, we measured a 3-m square in which $2-5$ samples per depth $(30 \mathrm{~cm}$ and $60 \mathrm{~cm})$ were taken, combined and partitioned to obtain a representative soil sample (ca. $2 \mathrm{~kg}$ ). Thus, eight cases and four control soil samples were taken and sent to the PUCP to determine total heavy metal content through ICP-OES according to the EPA method 200.7-Rev. 4.4. [50]. Table 3 shows that the geological characteristics and the natural presence of relevant heavy metal. 
Table 3. Geological characteristics and natural HM presence in soil sample points and their surroundings.

\begin{tabular}{|c|c|c|c|c|c|}
\hline \multirow[b]{2}{*}{ Sub-Basin } & \multirow{2}{*}{$\begin{array}{l}\text { Sample } \\
\text { Point }\end{array}$} & \multicolumn{2}{|c|}{ Lithology and Geochemistry } & \multicolumn{2}{|c|}{ Surroundings to Sample Points } \\
\hline & & $\begin{array}{l}\text { Geological } \\
\text { Unit }\end{array}$ & HM & Geological Unit & HM \\
\hline \multirow{3}{*}{ Cunas } & $12 \mathrm{~km}$ & $\begin{array}{l}\text { Glacial, fluvial } \\
\text { D. (Q-glfl) }\end{array}$ & $\mathrm{Cr}$ & Casapalca F. (KsP-c) & $\mathrm{Cr}$ \\
\hline & $24 \mathrm{~km}$ & $\begin{array}{l}\text { Alluvial D. } \\
\text { (Q-al) }\end{array}$ & As, $\mathrm{Cr}, \mathrm{Cd}$ & $\begin{array}{l}\text { Mataula F. (Np-m) } \\
\text { Casapalca F. (KsP-c) }\end{array}$ & \\
\hline & Control & $\begin{array}{l}\text { Glacial, fluvial } \\
\text { D. (Q-glfl) }\end{array}$ & $\mathrm{Cr}$ & $\begin{array}{l}\text { Alluvial D. (Q-al) } \\
\text { Casapalca F. (KsP-c) } \\
\text { Matula F. (Np-m) }\end{array}$ & \\
\hline \multirow{3}{*}{ Aimaraes } & $12 \mathrm{~km}$ & $\begin{array}{l}\text { Glacial D. } \\
\text { (Q-gl) }\end{array}$ & $\mathrm{Cr}, \mathrm{Hg}, \mathrm{As}, \mathrm{Pb}$ & $\begin{array}{l}\text { Condorsinga F. (Ji-c) } \\
\text { Cercapuquio F. (Jm-c) }\end{array}$ & $\mathrm{Cr}$ \\
\hline & $24 \mathrm{~km}$ & $\begin{array}{l}\text { Colluvial D. } \\
\text { (Q-cl) }\end{array}$ & $\mathrm{Cr}, \mathrm{As}, \mathrm{Cd}, \mathrm{Pb}$ & $\begin{array}{c}\text { Yanacancha F. (N-ya) } \\
\text { Riolita (Nri) }\end{array}$ & \\
\hline & Control & $\begin{array}{l}\text { Alluvial D. } \\
\text { (Q-al) }\end{array}$ & $\mathrm{Cr}$ & $\begin{array}{l}\text { Condorsinga F. (Ji-c) } \\
\text { Yanacancha F. (N-ya) }\end{array}$ & \\
\hline
\end{tabular}

D.: Deposit, F.: Formation; based on $[73,79,82]$.

Although this research offers a more comprehensive and interdisciplinary insight into the mining companies-communities interactions, several drawbacks are to be acknowledged. These mainly relate to the restrictions on water and soil sampling due to mining companies' demarcations, privatization, and latent territorial conflict between communities.

\subsection{Participatory Mapping}

In the Usibamba community, a participatory mapping exercise was conducted following the methods of Ramirez-Gomez [56]. As there is no agreement with the Azulcocha mine, community members rely strongly on farming for their livelihoods [83]. Mining impacts have been reported because of the effects on community livelihoods. Via participatory mapping, we aimed (i) to identify community settlements, livestock water sources, and grazing and agriculture areas, and (ii) to contrast the site conditions with our results on heavy metal content and land-cover classification, and with official reports from the regional government (e.g., available community maps) and the OEFA [84,85]. The exercise was in two stages. In the first stage (11 March 2017), ten volunteer community members participated, and in the second (23 March 23 2017) two key informants plus nine neighborhood presidents. In both cases, a detailed map including roads and streams as well as a digital elevation model (DEM) of the 90-m resolution was used. The DEM was obtained from the Shuttle Radar Topography Mission [86]).

The participatory mapping outcomes were overlaid with a land-cover classification (LCC) that considered crops, infrastructure, rocky outcrops, vegetation, and water for which two Landsat surface reflectance images from the U.S. Geological Survey [87] were processed. These images belong to Path 6 and Rows 68 (10.64\% cloud cover) and 69 (0\% cloud cover) taken on 07 August and 22 July in 2017 (dry season). The LCC consisted of the following processing steps: (1) normalize topographic shadow on images (bands 2-7) with the Minnaert algorithm [88] (Appendix C), (2) extract training/validation samples, (3) apply a maximum likelihood classification (MLC) [55], and (4) reclassify misclassified pixels (Appendix D) by comparing results with participatory mapping zonification and high-resolution imagery from Google [89]. The resulting product is shown in Figure 4. 


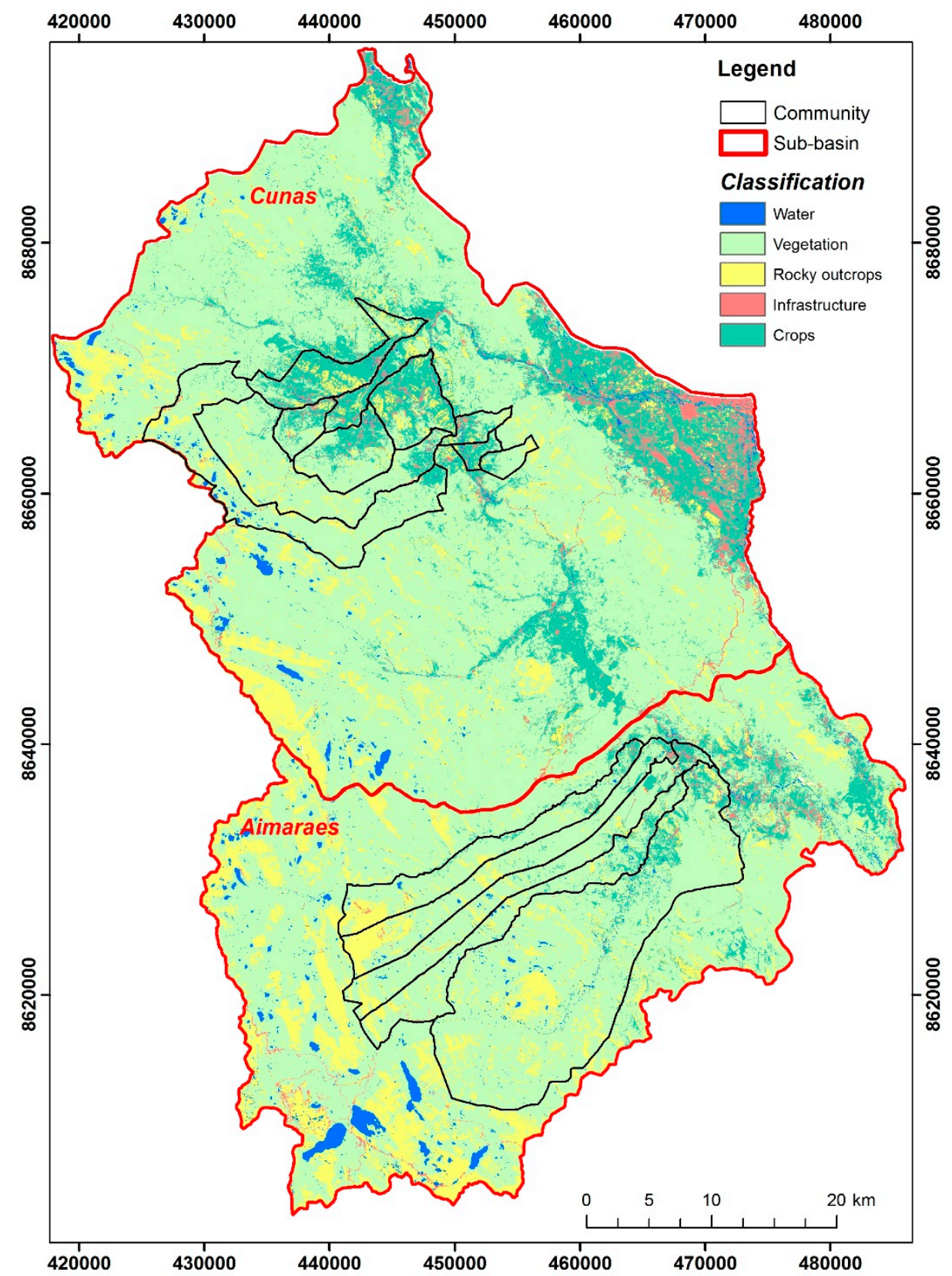

Figure 4. Land-cover classification based on the reclassification of the maximum likelihood classification method.

In total, 1647 samples were randomly taken considering a minimum distance of $\sim 1 \mathrm{~km}$ between each sample. From these, we selected 1320 samples for training and reserved 327 for validation (i.e., $80 \%$ training and $20 \%$ validation). During the training, for each land cover class, we took 280 samples, except in infrastructure which accounts for 200 samples since minimum distance did not allow us to sample more than this number. Similarly, for validation, we took 70 samples for each land cover class, except in infrastructure where we took 47 samples. The confusion matrix is presented in Table 4.

The accuracy metrics calculated indicated that the map achieved an overall precision of 0.90 . The class crops indicated that omission error was the highest in the map while vegetation was for the commission error. Nevertheless, Kappa indicated a score 0.87 , which is considered strong $(64-81 \%$ of data are reliable) [90]. Because the Usibamba community was considered for participatory mapping, 
the reclassified LCC map was focused on this community for its later integration with the heavy metal contents and secondary data.

Table 4. Confusion matrix of land-cover classification.

\begin{tabular}{ccccccccc}
\hline \multirow{2}{*}{ Land Cover Classes } & \multicolumn{3}{c}{ Reference(Number of Samples) } & \multicolumn{2}{c}{ Row Total } \\
\cline { 3 - 8 } & & $\mathbf{1}$ & $\mathbf{2}$ & $\mathbf{3}$ & $\mathbf{4}$ & $\mathbf{5}$ & Total & Commission \\
\hline \multirow{4}{*}{ Predicted } & 1. Crops & 57 & 2 & 0 & 4 & 0 & 63 & 0.09 \\
& 2. Infrastructure & 2 & 45 & 1 & 0 & 0 & 48 & 0.06 \\
& 3. Rocky outcrop & 3 & 0 & 59 & 0 & 1 & 63 & 0.06 \\
& 4. Vegetation & 6 & 0 & 10 & 65 & 0 & 81 & 0.19 \\
\hline Column & 5. Water & 2 & 0 & 0 & 1 & 69 & 72 & 0.04 \\
total & Total & 70 & 47 & 70 & 70 & 70 & & \\
\hline
\end{tabular}

\section{Results}

\subsection{Agreements between Mining Companies and Communities}

We previously assumed that the main stakeholders were the mining companies, sub-national government, and campesino communities. However, the meetings with campesino communities revealed that an agreement is only between the community and the mining company representatives. During our meetings, campesino communities indicated that the agreements reached with the mining companies were weak and often tended to be dissolved from the very beginning up to the end. In other words, the agreements were rarely kept to. To understand the reasons behind this, in-depth interviews were undertaken to explore (1) how an agreement is established, (2) the clauses it contains, and (3) the communities' expectations regarding the agreements.

Agreements include social, economic and environmental clauses. The community's corresponding benefits depend on the stage of the intervention of the mining company. For example, during the exploration stage, benefits mainly focus on the annual payment and job quotas (personal conversations with Huacravilca representatives). During the exploitation stage, better benefits are offered (pers. conv. with Huacravilca and Corihuarmi representatives). The main economic clause refers to the annual payment to the community, which depends on the negotiation capacity of both stakeholders (pers. conv. with representatives of Huacravilca). The negotiation of the agreement is usually long (e.g., six months), depending on the mining-related negotiating position of the community and the occurrence of previous experiences. Negotiations start with the mining company establishing contact with the president of the community or an accessible community authority (pers. conv. with Volcan, Huacravilca and Corihuarmi representatives), since a good relationship with a community authority is crucial to the desired outcome. An example of this negotiation is given by the representative of the Cunas sub-basin:

"In the first meeting with (the mine) Azulcocha, Shicuy (community) authorities requested balls for the children, food supplies and 10000 PEN/year in return for the rent of 700 ha of land. Shortly after, Shicuy realized the real price of land rent and tried to change the agreement (...) The situation escalated into a conflict as Azulcocha refused initially (... ) Finally, better clauses were negotiated and the agreement changed, now the payment is 300000 PEN/year." (LQ, representative of Cunas sub-basin, Tambo, 2016)

Once the annual payment is set, the campesino community usually adds other economic clauses such as a job quota for community members, installation of productive projects (e.g., promotion of small-animal farming), and work for the community-formed companies that can provide services to the mine (pers. conv. with Volcan representative and representative of Cunas sub-basin). Regarding the social clause, the mining company sustains projects such as the provision of sports clothes for school children, financing of a school library, school materials for children, annual health campaigns, prizes, 
and transportation for community members. The environmental clause may include the commitment of the mine to re-forest eroded areas and carry out participatory monitoring of the environmental impacts, mainly water quality (pers. conv. with Corihuarmi representative).

However, community authorities have expressed that most clauses of the agreement are not fully accomplished (pers. conv. with Shicuy community authority). Regarding the breaching of the environmental clause, community authorities often mention pollution in higher zones (upstream headwaters), which affect wildlife and livestock. For instance, the Chongos Alto community authority said that:

"Community members who visited upstream zones reported that they saw signs of pollution due to mining activities". (PH, representative of Chongos Alto, Huancayo, 2016)

At the end of the year, the benefited community signs a certificate of compliance when the agreement has been fulfilled (pers. conv. with Huacravilca and Corihuarmi representatives). However, neighboring communities may also experience the indirect impacts of mining activities but have no agreement. These communities expect to be included in the consultation process and considered for a mining-community agreement:

"Llamapsillon (neighboring community of Chongos Alto) does not have any agreement with Huacravilca mine ... There should be a prior consultation including all neighboring communities, as they did with the directly affected community, so we can have the possibility to accept or not their activities". (BC, representative of Llamapsillon, Llamapsillon, 2016)

\subsection{Mining Impact on Water Streams}

Our water results were compared with the values reported by the Peruvian monitoring agency (i.e., OEFA) to provide the historical background. OEFA inspected the Corihuarmi mine three times (2010, 2012 and 2013), and the Azulcocha mine twice in 2013 (Appendix B: Tables A1 and A2). In the Cunas sub-basin, we took eight case samples at $100 \mathrm{~m}$ upstream (B-AM) and $500 \mathrm{~m}$ downstream (A-AM) of the Azulcocha concentrator plant, at the confluence of the Tambo and Consac rivers (I-N), and $500 \mathrm{~m}$ downstream of the Usibamba community (A-UC). We also took four control samples (B-UC and P-N) at non-mining sites (Figure 5a). In the Aimaraes sub-basin, we took eight case samples at $500 \mathrm{~m}$ downstream of the Corihuarmi mine (A-CM), ca. $500 \mathrm{~m}$ downstream of the disputed area (A-CA-S), and $500 \mathrm{~m}$ upstream (B-HM), and $500 \mathrm{~m}$ (A-HM) downstream of the exploration platforms of Huacravilca. Here we also took four control samples (L-S and I-L) at two non-mining sites (Figure 5b).

In Tables 5 and 6, the results from the OEFA and our results show where total metal concentrations were higher than the EQS. The total metal concentrations of the control and remaining case sample points were lower than the EQS (Tables A3-A5 of Appendix B). In the Cunas sub-basin, the sample point downstream of Azulcocha (A-AM) showed high concentrations of As, Cd, and manganese (Mn), metals that are geologically absent in the area (Table 2). Compared to the OEFA reports [84,85], in 2013 the As and Cd levels in the Huasi Viejo stream of the Cunas sub-basin were also high (Figure 5a). The highest concentration of As was $13.43 \mathrm{mg} \mathrm{L}^{-1}$ in e02 at $100 \mathrm{~m}$ from our A-AM sample point. In this sample, there was also a higher concentration of $\mathrm{Mn}$, which is related to the enhancement of the oxidation of arsenite in manganese oxides. In the Aimaraes sub-basin, our sample point upstream of Huacravilca (B-HM) and OEFA results showed a $\mathrm{pH}$ between 6.5 and 9, which is within the accepted $\mathrm{pH}$ range for Andean rivers [75]. B-HM revealed a high concentration of $\mathrm{Cd}, \mathrm{Mn}$, and iron (Fe), but there were no reports by the OEFA in the surroundings of the sample point with which to compare because Huacravilca started the exploration in 2016. 

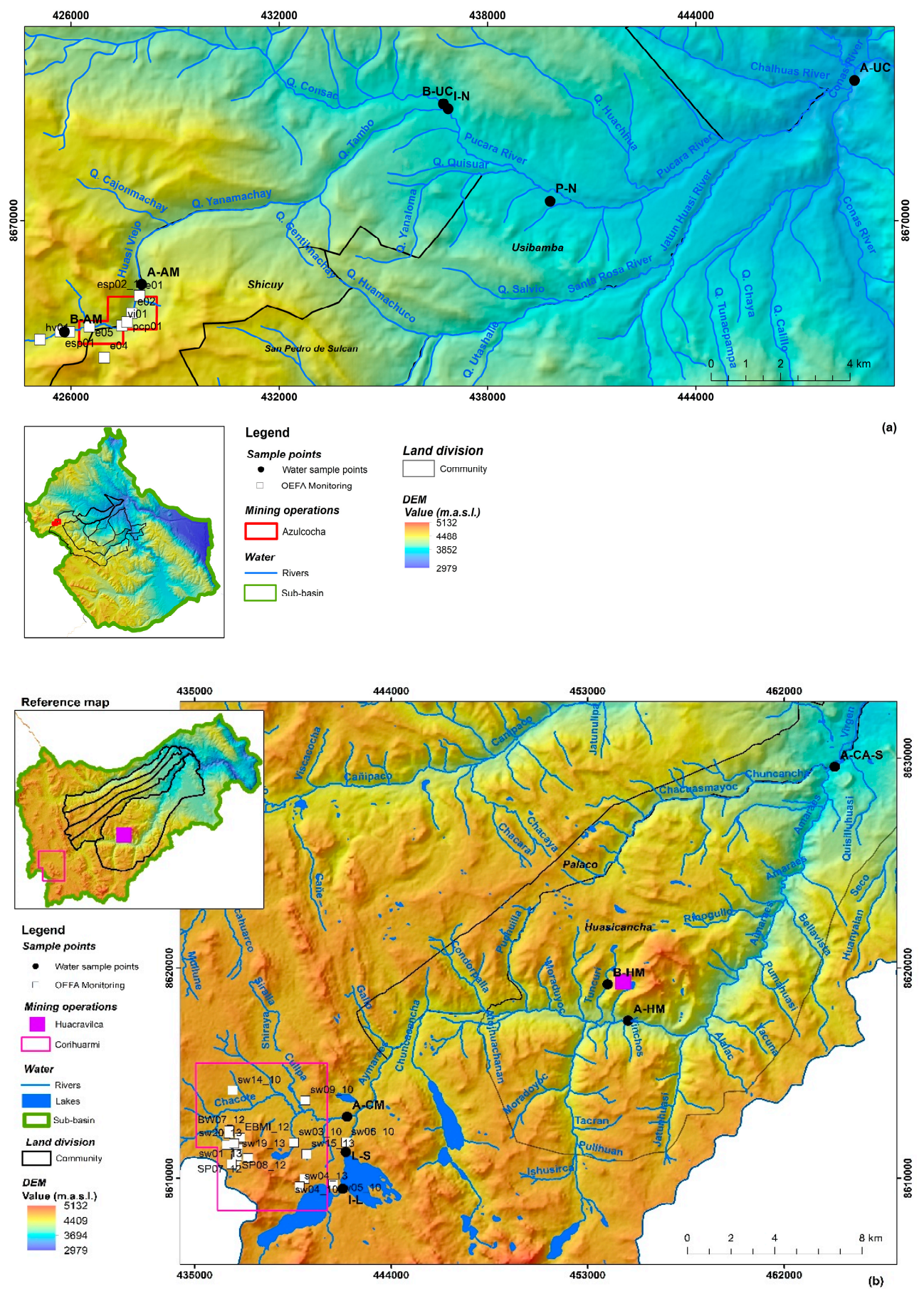

Figure 5. Water monitoring and elevation in (a) Cunas and (b) Aimaraes sub-basins (based on $[84,85,91-93])$.

\subsection{Mining Impact on Soil}

Table 7 shows that the contents of As, $\mathrm{Cd}$ and/or Pb exceed at least in some cases the EQS [94]. In the Cunas sub-basin, we took four case samples at $12 \mathrm{~km}$ and $24 \mathrm{~km}$ downstream of the Azulcocha mining site as well as two control samples at non-mining sites. In all soil sample sites, there was a high presence of $\mathrm{Cd}$ at $30 \mathrm{~cm}$ and $60 \mathrm{~cm}$ depth. This may be explained by the geochemistry of the research area [73] (Table 3) characterized by the presence of As and Cd $24 \mathrm{~km}$ downstream. While this situation may explain the high concentrations of $\mathrm{Cd}$ and $\mathrm{As}$, it does not explain that of $\mathrm{Pb}$. 
Table 5. Total metal concentrations $\left(\mathrm{mg} \mathrm{L}^{-1}\right)$ in water samples exceeding Environmental Quality Standards (EQS) in the Cunas sub-basin.

\begin{tabular}{|c|c|c|c|c|c|c|}
\hline & Site & $\mathrm{pH}$ & $\mathrm{Zn}$ & As & $\mathrm{Cd} \times 10^{-2}$ & Mn \\
\hline \multirow{2}{*}{ EQS } & Irrigation & $6.5-9$ & 2 & 0.1 & 1.0 & 0.2 \\
\hline & $\begin{array}{l}\text { Livestock } \\
\text { drinking }\end{array}$ & $6.5-9$ & 24 & 0.2 & 5.0 & 0.2 \\
\hline \multirow{2}{*}{ This research * } & $1 \mathrm{~A}-\mathrm{AM}$ & \multirow{2}{*}{7.8} & 12.3 & 0.6 & 2.3 & 18.5 \\
\hline & $2 \mathrm{~A}-\mathrm{AM}$ & & 12.5 & 0.6 & 2.2 & 18.7 \\
\hline \multirow{7}{*}{ OEFA report * } & $\mathrm{e} 01$ & 8.2 & 0.2 & 3.0 & $<0.0004$ & 18.1 \\
\hline & $\mathrm{e} 02$ & 8.1 & 0.2 & 13.4 & $<0.0004$ & - \\
\hline & pсp01 & 8.0 & 1.1 & 0.3 & 0.2 & 2.3 \\
\hline & hv01 & 8.3 & 0.1 & 0.1 & $<0.0004$ & 0.1 \\
\hline & esp01_14 & 8.0 & 0.1 & 0.1 & 0.1 & 0.1 \\
\hline & esp02_14 & 7.9 & 0.3 & 3.0 & 0.2 & 19.8 \\
\hline & vi01 & 8.2 & 0.8 & 0.2 & 1.0 & - \\
\hline
\end{tabular}

* In these sample points, INGEMMET did not report the presence of heavy metals in 2017.

Table 6. Total metal concentrations $\left(\mathrm{mg} \mathrm{L}^{-1}\right)$ in water samples exceeding EQS in the Aimaraes sub-basin.

\begin{tabular}{cccccccc}
\hline & Site & $\mathbf{p H}$ & $\mathbf{C u}$ & $\mathbf{A s}$ & $\mathbf{C d} \times \mathbf{1 0}^{-\mathbf{1}}$ & $\mathbf{F e}$ & $\mathbf{M n}$ \\
\hline \multirow{2}{*}{ EQS } & $\begin{array}{c}\text { Irrigation } \\
\text { Livestock } \\
\text { drinking }\end{array}$ & $6.5-9$ & 0.2 & 0.1 & 0.1 & 5 & 0.2 \\
& $6.5-9$ & 0.5 & 0.2 & 0.5 & - & 0.2 \\
\hline This & 1 B-HM & 5.4 & 0.071 & $<0.010$ & 0.1 & 50.0 & 2.1 \\
research * & 2 B-HM & & 0.072 & $<0.010$ & 0.1 & 52.0 & 2.1 \\
\hline & sw02_10 & 4.6 & 0.2 & 0.5 & 0.1 & 36.1 & 0.4 \\
By OEFA * * & sw10_10 & 4.4 & 0.0 & $<0.005$ & 0.0 & 4.1 & 0.4 \\
& sw14_10 & 5.0 & 0.0 & 0.0 & 0.0 & 0.4 & 1.1 \\
& EBMI & 4.2 & 0.3 & 0.0 & - & - & - \\
& sw10_13 & 3.2 & 0.1 & 0.1 & 0.0 & 16.5 & 0.9 \\
& sw20_13 & 3.3 & 0.1 & 0.1 & 0.0 & 16.6 & 0.9 \\
& sw01_13 & 3.1 & 0.1 & 0.0 & $<0.0024$ & 25.9 & 1.4 \\
\hline
\end{tabular}

${ }^{*}$ In these sample points, INGEMMET did not report the presence of heavy metals in 2017.

Table 7. Total heavy metal contents $\left(\mathrm{mg} \mathrm{Kg}^{-1}\right)$ in soil samples exceeding EQS in the Cunas sub-basin.

\begin{tabular}{|c|c|c|c|c|c|}
\hline & Sample & As & $\mathrm{Cd}$ & $\mathrm{Cr}$ & $\mathrm{Pb}$ \\
\hline EQS & Farming soil & 50 & 1.4 & * & 70 \\
\hline \multirow{2}{*}{$\begin{array}{l}\text { Control } \\
\text { samples }\end{array}$} & Control-30 cm & 26.5 & 1.6 & 14.8 & 13.8 \\
\hline & Control- $60 \mathrm{~cm}$ & 20.7 & 1.8 & 16.8 & 9.9 \\
\hline \multirow{4}{*}{ Case samples } & $12 \mathrm{~km}-30 \mathrm{~cm}$ & 330.2 & 4.8 & 9.8 & 103.8 \\
\hline & $12 \mathrm{~km}-60 \mathrm{~cm}$ & 78.1 & 2.4 & 14.8 & 17.1 \\
\hline & $24 \mathrm{~km}-30 \mathrm{~cm}$ & 77.5 & 2.7 & 19.4 & 26.2 \\
\hline & $24 \mathrm{~km}-60 \mathrm{~cm}$ & 62.6 & 2.6 & 17.4 & 27.7 \\
\hline
\end{tabular}

* Based on supreme decree $\mathrm{N}^{\circ}$ 011-2017-MINAM [94], total $\mathrm{Cr}$ is not a parameter in farming soil. However, this study aimed to indicate the $\mathrm{Cr}$ contents.

In the Aimaraes sub-basin, a parallel sampling procedure was implemented. Here, four case samples were taken in the aforementioned layers at both $12 \mathrm{~km}$ and $24 \mathrm{~km}$ downstream of the Corihuarmi mine, plus two control samples at non-mining sites. Table 8 shows that the contents of As and Cd are higher than the EQS in $12 \mathrm{~km}$ downstream of Corihuarmi. These may relate to the 
geochemistry of the site. A similar situation is observed $24 \mathrm{~km}$ downstream (Table 3) for Cd. For the control sites, $\mathrm{Cd}$ is above the EQS, but the site geochemistry only indicates the presence of $\mathrm{Cr}$ (Table 8).

Table 8. Total heavy metal contents $\left(\mathrm{mg} \mathrm{kg}^{-1}\right)$ of soil samples exceeding EQS in the Aimaraes sub-basin.

\begin{tabular}{|c|c|c|c|c|c|}
\hline & Sample & As & $\mathrm{Cd}$ & Hg & $\mathrm{Cr}$ \\
\hline EQS & Farming soil & 50.0 & 1.4 & 6.6 & * \\
\hline \multirow{2}{*}{$\begin{array}{l}\text { Control } \\
\text { samples }\end{array}$} & Control-30 cm & 13.3 & 3.3 & $<2.0$ & 27.8 \\
\hline & Control- $60 \mathrm{~cm}$ & 13.2 & 3.1 & $<2.0$ & 26.4 \\
\hline \multirow{4}{*}{ Cases samples } & $12 \mathrm{~km}-30 \mathrm{~cm}$ & 84.6 & 4.4 & 9.4 & 22.4 \\
\hline & $12 \mathrm{~km}-60 \mathrm{~cm}$ & 99.9 & 4.0 & 5.4 & 20.8 \\
\hline & $24 \mathrm{~km}-30 \mathrm{~cm}$ & 11.9 & 2.7 & $<2.0$ & 18.4 \\
\hline & $24 \mathrm{~km}-60 \mathrm{~cm}$ & 6.9 & 2.8 & $<2.0$ & 17.4 \\
\hline
\end{tabular}

${ }^{*}$ Based on supreme decree $\mathrm{N}^{\circ}$ 011-2017-MINAM [94], total $\mathrm{Cr}$ is not a parameter in farming soil. However, this study aimed to indicate the $\mathrm{Cr}$ contents.

\subsection{Community Livelihoods and Mining Impact}

In the Cunas sub-basin, the Shicuy community rents its lands to the Azulcocha mine through an agreement. However, Usibamba authorities affirmed that the flow of the Pucara river transports the mining impacts downstream to the Shicuy community. The authorities expressed concern since they use the river water for grazing and agriculture. This concern is supported by the aforementioned water results, which indicate high concentrations of arsenic and cadmium downstream of the Azulcocha concentrator plant. Interestingly, the Usibamba community does not want to settle an agreement with Azulcocha but rather to protect its livestock and dairy production on which its economy is based.

Figure 6 shows the LCC and the land use proposed during the participatory mapping exercise. The LCC assessed the current land use in Usibamba and contrasted it with the established croplands (highlighted in bright green) and settlements identified during participatory mapping. Vegetation represents natural pastures grazed by the livestock of the Usibamba farmers. These livestock drink water from the Pucara and Jatun Huasi rivers. It is suspected that the Pucara river is affected by mining activities (pers. conv. with Usibamba authorities), which in turn pollute the Huasi Viejo, Yanamachay and Tambo rivers. When asked about this, the Azulcocha mine representative stated that the Azulcocha mine uses its concentrator plant for processing extractions from other mining concessions (outside of our research area), and the granted water use is done properly. However, Azulcocha was fined in 2013 due to the lack of prevention measures related to water accumulation in mining tailings [95].

Figure 6 shows the water and soil sample sites and also the INGEMMET sites (i.e., geochemistry database) with the Cd and As that had higher contents than the EQS. Based on the LCC, the crop areas might be influenced by the geochemistry of the area. Regarding Azulcocha, the INGEMMET did not record the presence of heavy metals near the mine. The aforementioned results of the OEFA support our findings of high concentrations of cadmium and arsenic downstream of the concentrator plant. Thus, the concerns of the Usibamba community regarding water and their livelihoods may well be justified. 


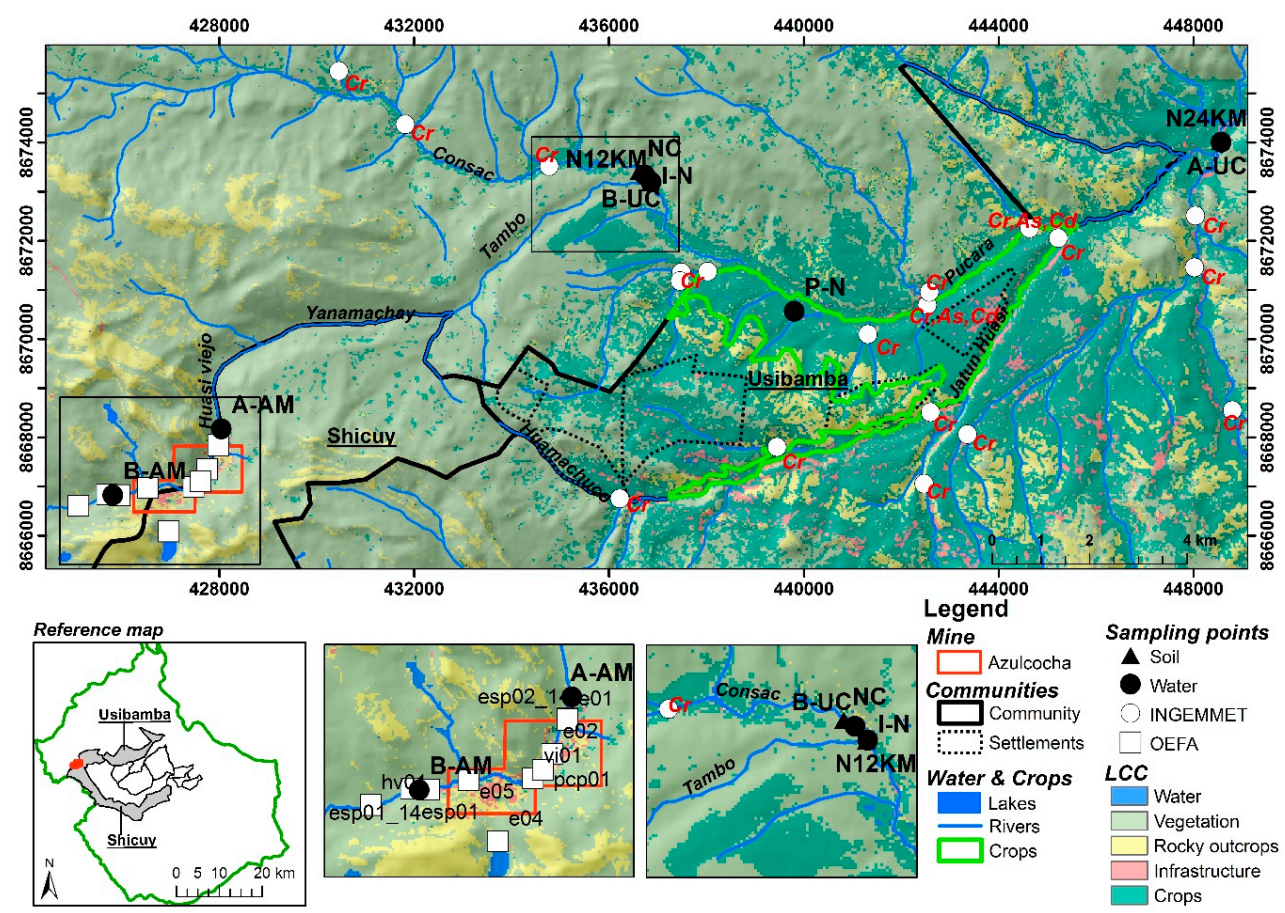

Figure 6. Land-cover classification and participatory mapping in Usibamba community. OEFA refers to the location of the samples collected by the OEFA in 2013. The locations of geochemistry values reported in 2014-2016 by the INGEMMET are indicated by white dots $(\bigcirc)$ with the relevant presence of heavy metals. In the case of As and Cd, they had higher concentrations than EQS. The locations of our water and soil results are referred to as water $(\bullet)$ and soil $(\mathbf{\Lambda})$. The Usibamba settlements are delineated by dotted lines. This figure is based on the participatory mapping, official community maps, INGEMMET [73], and OEFA reports [95].

\section{Discussion}

This study provides an insight into the negotiations between mining operations and communities operationalized through an agreement. This agreement is established via a regularly negotiation process in which the expectations and needs of the campesino communities are supposed to be met by the mining company as a counterpart. These negotiations are guided by previous experiences, the negotiation skills of the community authorities, and the knowledge on the mining potential of the community lands. It should be noted that there are also communities that oppose the signing of these agreements $[19,96]$. Despite the economic offset, communities remain concerned about the impacts of mining on water quality, livelihoods, and the general health of the ecosystems [12,97]. To analyze mining impacts on farming lands, we compared the heavy metal concentrations exceeding the EQS in our results with the results of the OEFA and the contents reported by the INGEMMET.

\subsection{Effects on the Environment}

Water quality testing in these sub-basins is novel. Previous studies have only focused on the Junin Lake, located between Cerro de Pasco mine and La Oroya mine, the latter one made the nearest city one of the top ten most polluted cities worldwide [97-99]. In the Cunas sub-basin, our results indicate that the total concentrations of arsenic and cadmium exceed the EQS. There is the possibility that the concentrator plant of the Azulcocha mine led to the high concentration of arsenic in the Huasi Viejo river given that arsenic is a by-product of metal smelting and a component of dust from metal ore roasting [100]. On the other hand, there are non-exploited areas within the Azulcocha mining concession where the presence of heavy metals may relate to its geogeny, and the detected arsenic may have been released through both natural weathering and mining production [101]. Since a higher concentration of manganese was also found, this might be related to the enhancement of the oxidation 
of arsenite in manganese oxides [101]. Arsenite could be the dominating element due to a $\mathrm{pH}<8$ (7.8) downstream of the Azulcocha concentrator plant. This situation has become a source of conflict because the Huasi Viejo river is used by the livestock in the Usibamba community located downstream.

In the Aimaraes sub-basin, we found high concentrations of cadmium, iron, and manganese, although the geochemical characteristics of the surroundings (Condorsinga formation) are not characterized by a natural occurrence of these elements. However, in the nearby Cercapuquio formation, zinc and cadmium are inherent elements, and the high cadmium concentration was possibly due to the neighboring abandoned and non-remediated Cercapuquio mine. After 1912, the Cercapuquio mine (W75 $\left.26^{\prime}-\mathrm{S} 12^{\circ} 25^{\prime}, 4380 \mathrm{MASL}\right)$ was irregularly exploited, for example producing $180 \mathrm{ton} /$ day of lead, zinc, and iron between 1935 and 1938 [102]. This mining was underground and located on an ore deposit (Cercapuquio ore) that provides lead (as $\mathrm{PbS}$ ), zinc (as $\mathrm{ZnS}$ ), silver (as a combination of $\mathrm{AgS}$ and $\mathrm{PbS})$, cadmium (as $\mathrm{CdS})$, manganese (as $\mathrm{MnO})$, and iron (as $\left.\mathrm{Fe}(\mathrm{OH})_{2}\right)$ [102]. The proximity of Cercapuquio ore to the B-HM sample point and the constant soil erosion may have influenced the presence of cadmium, iron, and manganese. Moreover, cadmium persistence may have led to its accumulation in the environment [103].

Our soil analyses indicate the presence of cadmium and arsenic in the case samples of both sub-basins, where the geology is characterized by the natural presence of chromium [73,78]. Chromium accumulates in the topsoil layer where it is absorbed and accumulated in plant roots with a small possibility of translocation to shoots [104,105]. Cadmium can also reach the roots of grass species [106]. In the research area, rough grass (Jarava ichu) is the main forage source of livestock (pers. conv. with community members). To better analyze the bioaccumulation, this study suggests an in-depth analysis of the cadmium and chromium concentrations obtained by plants, animals and human consumers [106]. In the light of our soil findings, we suggest several possible reasons for the high heavy metal contents: (1) the long-term mining activity that has led to transportation of heavy metals to water streams, (2) the soil erosion and proximity to the Cercapuquio ore, and (3) the airborne transportation of heavy metals from the long-term use of smelters at the La Oroya mine. Regarding the first reason, this might explain the presence of arsenic in the soils. Streams crossing the zones erode and disperse soils thus dragging arsenic and lead downstream that eventually reach the flood plain, and is a more intense process during the rainy season [107]. Regarding the second reason, we overlaid our results with the geochemical characteristics of the site reported by the INGEMMET [73]. The presence of chromium is due to the underground lithological units. The high contents of other heavy metals (e.g., arsenic and cadmium) might be related to the geology, but could also be influenced by the long history of mining, e.g., the Cercapuquio mine was abandoned in the early twentieth century and never remediated. Regarding the third reason, since 1922 the three smelters at the La Oroya mine-located $167 \mathrm{~km}$ north-west from Cercapuquio- -have emitted non-regulated toxic smokes that have affected land and water bodies, presumably including the Cunas sub-basin [83,108-110]. Although the air transportation of cadmium, lead and arsenic mostly occurs in short distances [111], there are reports that this has also occurred over great distances from the smelters [83]. From 2002 to 2007, the emissions from La Oroya contained cadmium, lead, and arsenic [112]. Cadmium particles (ca. $1 \mu \mathrm{m})$ can travel for days depending on meteorological parameters and the density of the particles [103].

\subsection{Effects on the Community Livelihoods}

The decrease in water and soil quality either directly or indirectly due to mining activities has affected the communities' livelihoods and unleashed land-use conflicts [113-115]. The negotiation process described above is often improperly conducted and neglects community members or leaves behind indirectly affected communities [116]. The participatory mapping and land-cover classification show how the Pucara river, which is possibly affected by mining, impacts other non-mining areas of a downstream community (Usibamba). Hence, the Usibamba community, relying mostly on livestock rearing, has developed an anti-mining position since the establishment of the Azulcocha mine. The community decided to prioritize the conservation of the environment for their development. Upstream 
and most-affected communities, like Shicuy, hold a different position. In Shicuy, their agreement awards them economic benefits (i.e., 300,000 PEN/year $\approx 80175 \mathrm{EUR} /$ year), and livestock are allowed to graze and drink near concession areas (pers. conv. with Shicuy authorities).

Regarding water access and quality, farmers agree that the pollutants in the tailing from the Azulcocha mining site leak out into the Huasi Viejo river. They then flow into the Consac river and later to the Pucara river, which is used by the Usibamba community farmers for watering livestock and other activities, e.g., crop irrigation. However, the bioaccumulation of heavy metals in crops and pastures was not explored and appears to remain a major challenge. Our research findings, matching previous studies, show that water insecurity due to poor water quality is triggered by mining sites located at headwaters [1,96]. The poorer water quality, causing water insecurity in the community jeopardizes the community's livelihoods [96,117] and prevents future negotiations with mining companies. This, taken together with disagreements arising from community interests, may be the seeds of future land-use conflicts.

\section{Conclusions}

The establishment of legal mining activities and the overlapping with the economic interests of communities trigger environmental concerns among communities regarding water and soil quality. Based on our study of three mining sites and 14 campesino communities, agreement clauses were identified that provide economic, social and environmental benefits in return for the rent of community land. However, not all communities can be considered for signing an agreement with the mining company, and many do not want to do this as was the case in Llamapsillon and Usibamba communities. Our study also revealed the impacts of heavy metal concentrations in water and soil that were linked to community livelihoods.

Mining impacts-in terms of heavy metals in soil and water-might affect downstream communities, including those who have no agreements with mining companies. Soil analyses show that cadmium and other metal contents were higher than the national EQS. The water analysis shows that concentrations of arsenic and cadmium near mining sites also exceeded the EQS. In contrast with results from the Peruvian monitoring agency and those based solely on the local geochemistry, our results indicate a relationship between the high concentrations of heavy metals and current mining activities, which cannot be attributed to the long-term mining exploitation of the region. The results of our study indicate that the livelihood of a neighboring community that does not have an agreement can be affected by mining activities in terms of livestock grazing and watering. Therefore, although the findings are significant, they are still indicative, and the heavy metal concentrations and bioaccumulation in the research area should be further explored. Finally, the findings of this interdisciplinary research have the potential to be used in other contexts to assess impacts on both the environment and community livelihoods at the intersection of mining and community interests.

Author Contributions: Conceptualization, M.R.Q.-Z., D.C.C., and K.G.; methodology, M.R.Q.-Z., F.S., and K.G.; software, M.Q.Z., F.S., and K.G.; validation, M.R.Q.-Z. and F.S.; formal analysis, M.R.Q.-Z. and K.G..; investigation, M.R.Q.-Z., D.C.C. and K.G.; resources, M.R.Q.-Z., D.C.C. and K.G.; data curation, M.R.Q.-Z., F.S. and K.G.; writing-original draft preparation, M.R.Q.-Z., D.C.C. and K.G.; writing—review and editing, M.R.Q.-Z., D.C.-C., F.S., and K.G.; visualization, M.R.Q.-Z., D.C.-C. and K.G.; supervision, D.C.-C. and K.G.; project administration, M.R.Q.-Z., D.C.-C. and K.G.; funding acquisition, M.R.Q.-Z.

Funding: This research was funded by the Fiat panis Foundation Pn. 30800138 and the German Academic Exchange-DAAD PKZ P/14/01271. M.R.Q.-Z. is also funded by DAAD Development-Related Postgraduate Courses 2015.

Acknowledgments: This research belongs to a doctoral dissertation hosted by the Center for Development Research. We wish to thank the 14 campesino communities who provided the opportunity to work with them and learn from them. We also want to thank the involved state institutions, local and regional authorities, and mining companies. The authors want to thank the Faculty of Chemistry Engineering of the National University of the Center of Peru for their logistic support during fieldwork. We also want to thanks the research assistants, Carlos and Fiorela, for their constant support during fieldwork and to Christian Borgemeister for his support along the study. Finally, we appreciate the anonymous Minerals reviewers for their constructive suggestions during the review process. 
Conflicts of Interest: The authors declare no conflict of interest.

\section{Appendix A}

Summary of guidelines of an in-depth interview with the representative(s) of mining operations and campesino communities.

\section{To mining operations:}

1. Which are the campesino communities directly and indirectly affected by the mining operations?

2. Which campesino communities have or had a mining-community agreement with the mining operation?

3. Which are the disagreements or conflicts within the community and with the mining operation?

4. Could you explain the process (negotiation) from the first contact to the signing of the agreement?

5. Which are the main difficulties in establishing dialogues that lead to the negotiation of the agreement?

6. How was the frequency of meetings with the mining company before and after signing the agreement?

7. How is the renewal of the mining-community agreement?

8. How has the relationship evolved between the mining operation and the campesino community from the first contact up to now?

9. Which are the main reasons for triggering a land-use conflict?

10. What are the main reasons for breaching the mining-community agreement?

\section{To campesino communities:}

1. Has your community had any contact with the mining project? If so, when and how was the first contact with the mining operation?

2. Has your community ever been contacted by another mining project? If so, how was this experienced?

3. How was the negotiation that lead to signing of the agreement?

4. How and why did your community accept signing a mining-community agreement?

5. Which are the clauses of the agreement?

6. Has your community changed after signing the agreement? If so, which are these changes?

7. Is your community satisfied with the accomplishment of the agreement?

8. Has the mining-community agreement been completely accomplished?

9. What are the main reasons for breaching the mining-community agreement?

10. Which are the main reasons for triggering a land-use conflict? 


\section{Appendix B}

Heavy metals concentrations in water and soil analyzed during this research and by state institutions.

Table A1. Total metal concentrations $\left(\mathrm{mg} \mathrm{L}^{-1}\right)$ in water samples evaluated by OEFA in Aimaraes sub-basin. Values exceeding EQS are in bold.

\begin{tabular}{|c|c|c|c|c|c|c|c|c|c|c|c|c|}
\hline Year & Code & $\mathrm{pH}$ & $\mathrm{Pb}$ & $\mathrm{Cu}$ & $\mathrm{Zn}$ & As & $\mathrm{Hg}$ & $\mathrm{Cr}$ & $\mathrm{Cd}$ & $\mathrm{Ni}$ & $\mathrm{Fe}$ & Mn \\
\hline \multirow{7}{*}{2010} & sw02_10 & 4.59 & $<0.005$ & 0.219 & 0.279 & 0.529 & $<0.0001$ & 0.007 & 0.009 & 0.036 & 36.12 & 0.4 \\
\hline & sw04_10 & 5.34 & $<0.005$ & 0.036 & 0.07 & 0.019 & $<0.0001$ & 0.002 & 0.0008 & 0.009 & 4.309 & 0.072 \\
\hline & sw05_10 & 8.27 & $<0.005$ & $<0.001$ & $<0.001$ & 0.008 & $<0.0001$ & $<0.001$ & $<0.0007$ & $<0.002$ & 0.148 & 0.033 \\
\hline & sw06_10 & 9.37 & 0.022 & 0.002 & 0.007 & 0.009 & $<0.0001$ & $<0.001$ & $<0.0007$ & $<0.002$ & 0.079 & 0.006 \\
\hline & sw09_10 & 8.14 & $<0.005$ & 0.002 & $<0.001$ & 0.007 & $<0.0001$ & $<0.001$ & $<0.0007$ & $<0.002$ & 0.044 & 0.045 \\
\hline & sw10_10 & 4.36 & $<0.005$ & 0.034 & 0.154 & $<0.005$ & $<0.0001$ & 0.002 & 0.0016 & 0.022 & 4.096 & 0.4 \\
\hline & sw14_10 & 4.96 & $<0.005$ & 0.038 & 0.184 & 0.006 & $<0.0001$ & $<0.001$ & 0.0013 & 0.018 & 0.44 & 1.148 \\
\hline \multirow{5}{*}{2012} & BW07_12 & 7 & 0.0008 & 0.0004 & 0.009 & 0.0009 & $<0.0001$ & $<0.0005$ & - & $<0.0004$ & - & 0.0093 \\
\hline & sw10_12 & 4.3 & 0.0124 & 0.0534 & 0.0974 & 0.0356 & $<0.0001$ & 0.0018 & - & 0.0117 & - & 0.378 \\
\hline & MA08_12 & 3 & 0.0209 & 0.0874 & 0.1494 & 0.0503 & $<0.0001$ & 0.0037 & - & 0.0205 & - & 0.1072 \\
\hline & MA02_12 & 8.4 & $<0.0002$ & 0.0002 & 0.0042 & 0.0007 & $<0.0001$ & $<0.0005$ & - & $<0.0004$ & - & 0.0056 \\
\hline & EBMI_12 & 4.2 & 0.0022 & 0.3256 & 1.0173 & 0.0068 & & - & - & - & - & \\
\hline \multirow{5}{*}{2013} & sw04_13 & 3.16 & $<0.010$ & 0.0085 & $<0.14$ & 0.0222 & $<0.0003$ & - & $<0.0024$ & - & 4.377 & 0.0911 \\
\hline & sw10_13 & 3.16 & $<0.010$ & 0.0968 & 0.24 & 0.0949 & $<0.0003$ & - & 0.003 & - & 16.5 & 0.896 \\
\hline & sw20_13 & 3.32 & $<0.010$ & 0.1046 & 0.26 & 0.0936 & $<0.0003$ & - & 0.0038 & - & 16.6 & 0.8772 \\
\hline & Sw01_13 & 3.09 & $<0.010$ & 0.1137 & 0.23 & 0.0492 & $<0.0003$ & - & $<0.0024$ & - & 25.851 & 1.3723 \\
\hline & sw19_13 & 3.11 & $<0.010$ & 0.131 & 0.21 & 0.0206 & $<0.0003$ & - & $<0.0024$ & - & 18.5 & 1.3533 \\
\hline
\end{tabular}

* Based on OEFA reports [91-93]. 
Table A2. Total metal concentrations $\left(\mathrm{mg} \mathrm{L}^{-1}\right)$ in water samples evaluated by OEFA in 2013 in Cunas sub-basin.

\begin{tabular}{|c|c|c|c|c|c|c|c|c|c|c|}
\hline Code & $\mathrm{pH}$ & $\mathbf{P b}$ & $\mathrm{Cu}$ & Zn & As & $\mathrm{Hg}$ & $\mathrm{Cr}$ & $\mathrm{Cd}$ & $\mathbf{F e}$ & Mn \\
\hline vi01 & 8.18 & $<0.001$ & 0.0135 & 0.779 & 0.23 & $<1$ & $<0.010$ & 0.01 & - & - \\
\hline $\mathrm{e} 02$ & 8.07 & 0.009 & $<0.0083$ & 0.196 & 13.43 & $<1$ & $<0.010$ & $<0.0004$ & - & - \\
\hline $\mathrm{e} 01$ & 8.24 & $<0.001$ & 0.0092 & 0.197 & 2.977 & $<0.00003$ & - & $<0.0004$ & 0.1232 & 18.11 \\
\hline e05 & 8.22 & $<0.001$ & 0.0117 & 0.082 & 0.050 & $<0.00003$ & - & $<0.0004$ & 0.3218 & 0.0479 \\
\hline pсp01 & 7.96 & $<0.001$ & 0.0111 & 1.057 & 0.333 & $<0.00003$ & - & 0.0016 & 0.5555 & 2.288 \\
\hline esp01 & 8.00 & $<0.001$ & 0.0101 & 0.077 & 0.088 & $<0.00003$ & - & $<0.0004$ & 0.1744 & 0.0307 \\
\hline e04 & 8.31 & $<0.001$ & 0.0078 & 0.044 & $<0.008$ & $<0.00003$ & - & $<0.0004$ & 0.0989 & 0.1464 \\
\hline hv01 & 8.27 & 0.009 & 0.0106 & 0.088 & 0.139 & 0.0007 & - & $<0.0004$ & 0.3655 & 0.0897 \\
\hline esp01_14 & 8.02 & $<0.001$ & 0.0105 & 0.088 & 0.102 & 0.0008 & - & 0.0012 & 0.5415 & 0.0504 \\
\hline esp02_14 & 7.92 & $<0.001$ & 0.0108 & 0.279 & 2.970 & 0.001 & - & 0.0016 & 0.1175 & 19.82 \\
\hline
\end{tabular}

Based on OEFA [84,85].

Table A3. Concentration ( $\mathrm{mg} \mathrm{L}^{-1}$ ) of total metals in water samples in this research in Cunas sub-basin.

\begin{tabular}{|c|c|c|c|c|c|c|c|c|c|c|c|}
\hline & Code & $\mathrm{pH}$ & As & $\mathrm{Cd}$ & $\mathrm{Ni}$ & $\mathrm{Hg}$ & $\mathrm{Pb}$ & $\mathrm{Cu}$ & $\mathrm{Fe}$ & Mn & $\mathrm{Zn}$ \\
\hline \multirow{4}{*}{ Control } & $1 \mathrm{I}-\mathrm{N}$ & \multirow[b]{2}{*}{9.68} & 0.017 & N.D. & N.D. & $<0.010$ & N.D. & $<0.004$ & 0.033 & 0.0055 & 0.004 \\
\hline & $2 \mathrm{I}-\mathrm{N}$ & & 0.015 & N.D. & N.D. & $<0.010$ & N.D. & $<0.004$ & 0.031 & 0.0055 & 0.004 \\
\hline & $1 \mathrm{P}-\mathrm{N}$ & \multirow{2}{*}{8.07} & $<0.010$ & N.D. & N.D. & $<0.010$ & N.D. & 0.005 & 0.006 & $<0.0003$ & $<0.003$ \\
\hline & $2 \mathrm{P}-\mathrm{N}$ & & $<0.010$ & N.D. & N.D. & $<0.010$ & N.D. & 0.005 & 0.012 & $<0.0003$ & 0.004 \\
\hline \multirow{8}{*}{ Cases } & 1 B-AM & \multirow{2}{*}{8.31} & 0.089 & N.D. & N.D. & $<0.010$ & N.D. & 0.005 & 0.111 & 0.025 & 0.007 \\
\hline & 2 B-AM & & 0.094 & N.D. & N.D. & $<0.010$ & N.D. & 0.006 & 0.112 & 0.026 & 0.009 \\
\hline & $1 \mathrm{~A}-\mathrm{AM}$ & \multirow{2}{*}{7.78} & 0.56 & 0.023 & 0.019 & $<0.010$ & $<0.028$ & 0.008 & 0.926 & 18.505 & 12.34 \\
\hline & $2 \mathrm{~A}-\mathrm{AM}$ & & 0.562 & 0.022 & 0.019 & $<0.010$ & $<0.028$ & 0.007 & 0.913 & 18.735 & 12.47 \\
\hline & 1 B-UC & \multirow{2}{*}{9.7} & 0.016 & N.D. & N.D. & $<0.010$ & N.D. & $<0.004$ & 0.032 & 0.0103 & 0.007 \\
\hline & 2 B-UC & & 0.017 & N.D. & N.D. & $<0.010$ & N.D. & $<0.004$ & 0.031 & 0.0065 & $<0.003$ \\
\hline & 1 A-UC & \multirow[b]{2}{*}{9.37} & 0.011 & N.D. & N.D. & $<0.010$ & N.D. & $<0.004$ & 0.022 & 0.0065 & $<0.003$ \\
\hline & 2 A-UC & & 0.016 & N.D. & N.D. & $<0.010$ & N.D. & $<0.004$ & 0.025 & 0.006 & 0.009 \\
\hline
\end{tabular}

N.D. < Detection limit in $\mathrm{mg} \mathrm{L}^{-1}$ : Cd (0.002), $\mathrm{Cu}(0.001), \mathrm{Cr}(0.002), \mathrm{Ni}(0.004)$ and $\mathrm{Pb}(0.009)$. 
Table A4. Total metal concentrations $\left(\mathrm{mg} \mathrm{L}^{-1}\right)$ in water samples in this research in Aimaraes sub-basin.

\begin{tabular}{|c|c|c|c|c|c|c|c|c|c|c|}
\hline & Code & $\mathrm{pH}$ & As & $\mathrm{Cd}$ & $\mathrm{Ni}$ & $\mathrm{Hg}$ & $\mathrm{Cu}$ & $\mathrm{Fe}$ & Mn & $\mathrm{Zn}$ \\
\hline \multirow{4}{*}{ Control } & $1 \mathrm{~L}-\mathrm{S}$ & \multirow{2}{*}{10.9} & $<0.010$ & N.D. & N.D. & $<0.01$ & $<0.004$ & 0.029 & 0.006 & 0.004 \\
\hline & $2 \mathrm{~L}-\mathrm{S}$ & & 0.011 & N.D. & N.D. & $<0.01$ & $<0.004$ & 0.056 & 0.006 & $<0.003$ \\
\hline & $1 \mathrm{I}-\mathrm{L}$ & \multirow{2}{*}{9.5} & $<0.010$ & N.D. & N.D. & $<0.01$ & 0.007 & 0.260 & 0.015 & 0.006 \\
\hline & $2 \mathrm{I}-\mathrm{L}$ & & $<0.010$ & N.D. & N.D. & $<0.01$ & 0.017 & 0.273 & 0.016 & 0.008 \\
\hline \multirow{8}{*}{ Cases } & $1 \mathrm{~A}-\mathrm{CM}$ & \multirow{2}{*}{9.18} & $<0.010$ & N.D. & N.D. & $<0.01$ & $<0.004$ & 0.017 & $<0.0003$ & 0.004 \\
\hline & $2 \mathrm{~A}-\mathrm{CM}$ & & $<0.010$ & N.D. & N.D. & $<0.01$ & 0.005 & 0.018 & 0.0035 & 0.007 \\
\hline & 1 B-HM & \multirow{2}{*}{5.4} & $<0.010$ & 0.006 & $<0.013$ & $<0.01$ & 0.071 & 50.020 & 2.140 & 0.102 \\
\hline & 2 B-HM & & $<0.010$ & 0.006 & $<0.013$ & $<0.01$ & 0.072 & 52.000 & 2.134 & 0.097 \\
\hline & $1 \mathrm{~A}-\mathrm{HM}$ & \multirow{2}{*}{9.9} & $<0.010$ & N.D. & N.D. & $<0.01$ & $<0.004$ & 0.032 & $<0.0003$ & $<0.003$ \\
\hline & 2 A-HM & & $<0.010$ & $<0,005$ & N.D. & $<0.01$ & $<0.004$ & 0.028 & $<0.0003$ & $<0.003$ \\
\hline & 1 A-CA-S & \multirow{2}{*}{9.83} & $<0.010$ & N.D. & N.D. & $<0.01$ & $<0.004$ & 0.023 & 0.005 & 0.004 \\
\hline & 2 A-CA-S & & $<0.010$ & N.D. & N.D. & $<0.01$ & $<0.004$ & 0.046 & 0.008 & 0.006 \\
\hline
\end{tabular}

N.D. $<$ Detection limit in $\mathrm{mg} \mathrm{L}^{-1}$ : Cd (0.002), $\mathrm{Cu}(0.001), \mathrm{Cr}(0.002), \mathrm{Ni}(0.004)$ and $\mathrm{Pb}(0.009)$.

Table A5. Environmental Quality Standards (EQS) $\left(\mathrm{mg} \mathrm{L}^{-1}\right)$ established by the Peruvian Ministry of Environment in 2017.

\begin{tabular}{|c|c|c|c|c|c|c|c|c|c|c|}
\hline Category (C) & Use & As & $\mathrm{Cd}$ & $\mathrm{Hg}$ & $\mathrm{Cr}$ & $\mathrm{Pb}$ & $\mathrm{Cu}$ & $\mathbf{F e}$ & Mn & Zn \\
\hline \multirow{2}{*}{ C3: Farming activities } & Irrigation & 0.1 & 0.01 & 0.001 & 0.1 & 0.05 & 0.2 & 5 & 0.2 & 2 \\
\hline & Livestock drinking & 0.2 & 0.05 & 0.01 & 1 & 0.05 & 0.5 & $\mathrm{n} / \mathrm{a}$ & 0.2 & 24 \\
\hline $\begin{array}{l}\text { C4: Conservation of } \\
\text { aquatic life }\end{array}$ & Andean rivers & 0.15 & 0.00025 & 0.0001 & 0.011 & 0.0025 & 0.1 & $\mathrm{n} / \mathrm{a}$ & $\mathrm{n} / \mathrm{a}$ & 0.12 \\
\hline
\end{tabular}




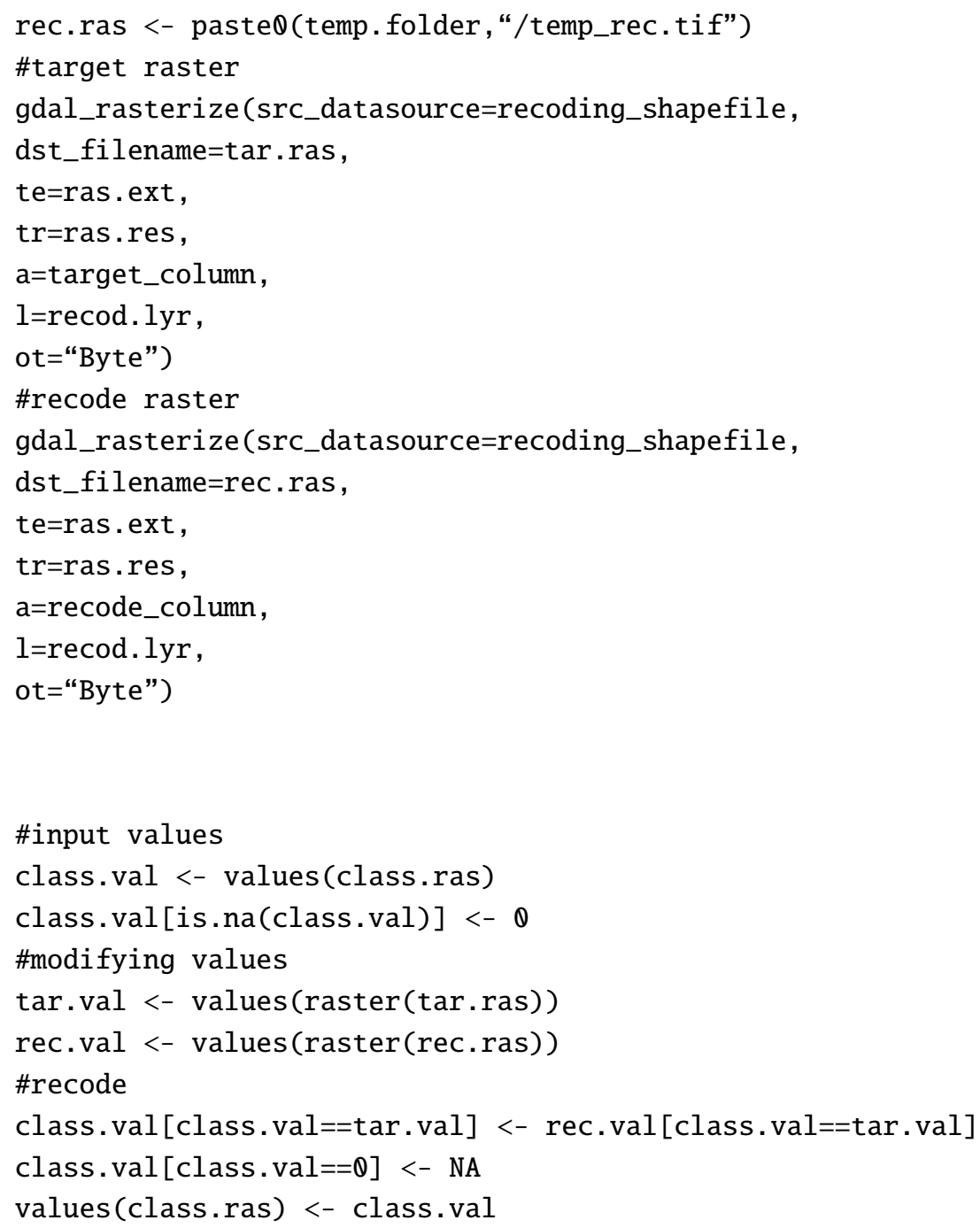

\section{References}

1. Bebbington, A.; Williams, M. Water and Mining Conflicts in Peru. Mt. Res. Dev. 2008, 28, 190-195. [CrossRef]

2. Becker, A.; Bugmann, H. Global Change and Mountain Regions: The Mountain Research Initiative. IGBP Rep. 2001, 49, 86 . 
3. Josse, C.; Cuesta, F.; Navarro, G.; Barrena, V.; Cabrera, E.; Chacón-Moreno, E.; Ferreira, W.; Peralvo, M.; Saito, J.; Tovar, A. Ecosistemas de Los Andes Del Norte y Centro. Bolivia, Colombia, Ecuador, Perú y Venezuela; Secretaría General de la Comunidad Andina, Programa Regional ECOBONA-Intercooperation, CONDESAN-Proyecto Páramo Andino, Programa BioAndes; EcoCiencia, NatureServe, IAvH, LTA-UNALM, ICAE-ULA, CDC-UNALM, RUMBOL SRL.: Lima, Peru, 2009.

4. Congreso de la República del Perú-CRP. Law N²4656-Ley General de Comunidades Campesinas; El peruano: Lima, Peru, 1987; p. 23.

5. Castillo, M.; Castillo, L.; Monge, C.; Bustamante, M. Las Comunidades Campesinas En El Siglo XXI: Situación Actual y Cambios Normativos, 1st ed.; Laos, F.A., Ed.; Grupo ALLPA—Comunidades y Desarrollo: Lima, Peru, 2004.

6. Comisión Técnica Regional Junín ZEE-CTRJ. Memoria Descriptiva Del Submodelo de Valor Histórico Cultural Del Departamento de Junín a Escala 1:100 000; Comisión Técnica Regional Junín ZEE-CTRJ: Huancayo, Peru, 2015.

7. Valdivia, C.; Quiroz, R. Coping and Adapting to Increased Climate Variability in the Andes. In Proceedings of the American Agricultural Economics Association Annual Meeting, Montreal, QC, Canada, 27-30 July 2003; pp. 1-28.

8. Kristjanson, P.; Krishna, A.; Radeny, M.; Kuan, J.; Quilca, G.; Sanchez-Urrelo, A.; Leon-Velarde, C. Poverty Dynamics and the Role of Livestock in the Peruvian Andes. Agric. Syst. 2007, 94, 294-308. [CrossRef]

9. Postigo, J.C.; Young, K.R.; Crews, K.A. Change and Continuity in a Pastoralist Community in the High Peruvian Andes. Hum. Ecol. 2008, 36, 535-551. [CrossRef]

10. Bartl, K.; Mayer, A.C.; Gómez, C.A.; Muñoz, E.; Hess, H.D.; Holmann, F. Economic Evaluation of Current and Alternative Dual-Purpose Cattle Systems for Smallholder Farms in the Central Peruvian Highlands. Agric. Syst. 2009, 101, 152-161. [CrossRef]

11. Arellano-Yanguas, J. A Thoroughly Modern Resource Curse? The New Natural Resource Policy Agenda and the Mining Revival in Peru; IDS Working Paper; 300; IDS: Brighton, UK, 2008.

12. Preciado Jerónimo, R. El Agua y Las Industrias Extractivas En El Perú: Un Análisis Desde La Gestión Integrada de Recursos Hídricos. In Agua e industrias extractivas Cambios y continuidades en los Andes; Urteaga, P., Ed.; Instituto de Estudios Peruanos: Lima, Peru, 2011; pp. 171-215.

13. Robbins, P. Political Ecology: A Critical Introduction, 2nd ed.; Robbins, P., Ed.; J. Wiley \& Sons: Oxford, UK, 2012.

14. Food and Agriculture Organization-FAO. Fishery Harbour Manual on the Prevention of Pollution-Bay of Bengal Programme. Available online: http://www.fao.org/documents/card/en/c/ede95f62-dcfc-59c9-b59820462a0488a3/ (accessed on 31 August 2017).

15. Järup, L. Hazards of Heavy Metal Contamination. Br. Med. Bull. 2003, 68, 167-182. [CrossRef]

16. Franks, D.M.; Davis, R.; Bebbington, A.; Ali, S.H.; Kemp, D.; Scurrah, M. Conflict Translates Environmental and Social Risk into Business Costs. Proc. Natl. Acad. Sci. USA 2014, 111, 7576-7581. [CrossRef]

17. Jaskoski, M. Environmental Licensing and Conflict in Peru's Mining Sector: A Path-Dependent Analysis. World Dev. 2014, 64, 873-883. [CrossRef]

18. Ministerio de Energía y Minas-MEM. Decreto Supremo-DS No 014-92-EM-Ley General de Minería; MEM: Lima, Peru, 1992; p. 68. [CrossRef]

19. Arellano-Yanguas, J. ¿Minería Sin Fronteras? Conflicto y Desarrollo En Regiones Mineras Del Perú, 1st ed.; Arellano-Yanguas, J., Ed.; Instituto de Estudios Peruanos, Pontificia Universidad Católica del Perú, Universidad Antonio Ruiz de Montoya: Lima, Peru, 2011.

20. Arellano-Yanguas, J. Local Politics, Conflict and Development in Peruvian Mining Regions. Ph.D. Thesis, University of Sussex, Brighton, UK, 2010.

21. Congreso de la República del Perú-CRP. Law N²7506—Ley Del Canon; Congreso de la República: Lima, Peru, 2001; p. 8.

22. Sociedad Nacional de Minería Petróleo y Energía-SNMPE. El Canon, Sobrecanon y Las Regalías En El Perú (2008-2017), 1st ed.; Sociedad Nacional de Minería Petróleo y Energía-SNMPE, Ed.; Sociedad Nacional de Minería Petróleo y Energía-SNMPE: Lima, Peru, 2018.

23. Congreso de la República del Perú-CRP. Law N ${ }^{\circ}$ 28322-Ley Que Modifica Artículos de La Ley N 27506; CRP: Lima, Peru, 2004; p. 3. 
24. Damonte, G.; Glave, M. Rent Distribution and Extractive Industry Conflicts: The Latin American Approach. Available online: https:/assets.publishing.service.gov.uk/media/57a08a5ee5274a27b2000575/121019_ECO_ ExtIndConMan_BRIEF3.pdf (accessed on 1 January 2012).

25. Defensoría del Pueblo-Ombudsman of Peru. Noveno Informe de La Defensoría Del Pueblo; Defensoría del Pueblo: Lima, Peru, 2005.

26. Defensoría del Pueblo-Ombudsman of Peru. Decimonoveno Informe Anual de La Defensoría Del Pueblo; Defensoría del Pueblo: Lima, Peru, 2014.

27. Defensoría del Pueblo-Ombudsman of Peru. Decimonoveno Informe Anual de La Defensoría Del Pueblo; Defensoría del Pueblo: Lima, Peru, 2015.

28. Defensoría del Pueblo-Ombudsman of Peru. Vigésimo Informe Anual de La Defensoría Del Pueblo; Defensoría del Pueblo: Lima, Peru, 2016.

29. Defensoría del Pueblo-Ombudsman of Peru. Vigésimo Primer Informe Anual de La Defensoría Del Pueblo; Defensoría del Pueblo: Lima, Peru, 2017.

30. Defensoría del Pueblo-Ombudsman of Peru. Décimo Informe Anual de La Defensoría Del Pueblo; Defensoría del Pueblo: Lima, Peru, 2006.

31. Defensoría del Pueblo-Ombudsman of Peru. Undécimo Informe Anual de La Defensoría Del Pueblo; Defensoría del Pueblo: Lima, Peru, 2007.

32. Defensoría del Pueblo-Ombudsman of Peru. Decimosegundo Informe Anual de La Defensoría Del Pueblo; Defensoría del Pueblo: Lima, Peru, 2008.

33. Defensoría del Pueblo-Ombudsman of Peru. Decimotercer Informe Anual de La Defensoría Del Pueblo; Defensoría del Pueblo: Lima, Peru, 2009.

34. Defensoría del Pueblo-Ombudsman of Peru. Decimocuarto Informe Anual de La Defensoría Del Pueblo; Defensoría del Pueblo: Lima, Peru, 2010.

35. Defensoría del Pueblo-Ombudsman of Peru. Decimoquinto Informe Anual de La Defensoría Del Pueblo; Defensoría del Pueblo: Lima, Peru, 2011.

36. Defensoría del Pueblo-Ombudsman of Peru. Decimosexto Informe Anual de La Defensoría Del Pueblo; Defensoría del Pueblo: Lima, Peru, 2012.

37. Defensoría del Pueblo-Ombudsman of Peru. Decimoséptimo Informe Anual de La Defensoría Del Pueblo; Defensoría del Pueblo: Lima, Peru, 2013.

38. Instituto Geológico Minero y Metalúrgico-INGEMMET. Atlas Catastral Minero y Geologico Del Peru; INGEMMET: Lima, Peru, 2017.

39. América Economía. Perú Iniciará Este año Nueve Proyectos Mineros por más de US\$11.500M| AméricaEconomía|AméricaEconomía. Available online: https:/www.americaeconomia.com/ negocios-industrias/peru-iniciara-este-ano-nueve-proyectos-mineros-por-mas-de-us $11500 \mathrm{~m}$ (accessed on 25 July 2018).

40. Hartman, H.L.; Mutmansky, J.M. Introductory Mining Engineering, 2nd ed.; Hartman, H.L., Mutmansky, J.M., Eds.; John Wiley \& Sons: Hoboken, NJ, USA, 2002.

41. Martín-Duque, J.F.; Sanz, M.A.; Bodoque, J.M.; Lucía, A.; Martín-Moreno, C. Restoring Earth Surface Processes through Landform Design. A 13-Year Monitoring of a Geomorphic Reclamation Model for Quarries on Slopes. Earth Surf. Process. Landf. 2010, 35, 531-548. [CrossRef]

42. King, B.; Goycoolea, M.; Newman, A. Optimizing the Open Pit-to-Underground Mining Transition. Eur. J. Oper. Res. 2017, 257, 297-309. [CrossRef]

43. Bebbington, A.; Bury, J. Institutional Challenges for Mining and Sustainability in Peru. Proc. Natl. Acad. Sci. USA 2009, 106, 17296-17301. [CrossRef] [PubMed]

44. Figueroa, E.; Orihuela, C.; Calfucura, E. Green Accounting and Sustainability of the Peruvian Metal Mining Sector. Resour. Policy 2010, 35, 156-167. [CrossRef]

45. McDonell, E. The Co-Constitution of Neoliberalism, Extractive Industries, and Indigeneity: Anti-Mining Protests in Puno, Peru. Extr. Ind. Soc. 2015, 2, 112-123. [CrossRef]

46. Bebbington, A.; Humphreys Bebbington, D.; Bury, J.; Lingan, J.; Muñoz, J.P.; Scurrah, M. Mining and Social Movements: Struggles Over Livelihood and Rural Territorial Development in the Andes. World Dev. 2008, 36, 2888-2905. [CrossRef]

47. Cathain, A.O.; Murphy, E.; Nicholl, J. Multidisciplinary, Interdisciplinary, or Dysfunctional? Team Working in Mixed-Methods Research. Qual. Health Res. 2008, 18, 1574-1585. [CrossRef] 
48. Hesse-Biber, S. Mixed Methods Research: Merging Theory with Practice, 1st ed.; Hesse-Biber, S.N., Ed.; Guilford Press: London, UK, 2010.

49. Hesse-Biber, S. Qualitative Approaches to Mixed Methods Practice. Qual. Inq. 2010, 16, 455-468. [CrossRef]

50. United States Environmental Protection Agency-EPA. Method 200.7-Rev. 4.4., Determination of Metals and Trace Elements in Water and Wastes by Inductively Coupled Plasma-Atomic Emission Spectrometry; Revision 4; EPA: Twinsburg, OH, USA, 1994.

51. Hagner, O.; Reese, H. A Method for Calibrated Maximum Likelihood Classification of Forest Types. Remote Sens. Environ. 2007, 110, 438-444. [CrossRef]

52. R Core Team. R: A Language and Environment for Statistical Computing; GBIF: Copenhagen, Denmark, 2015; ISBN 3-900051-07-0. Available online: http://www.R-project.org/ (accessed on 30 July 2018).

53. Hijmans, R.J.; van Etter, J.; Cheng, J.; Mattiuzzi, M.; Summer, M.; Greenberg, J.A.; Lamigueiro, O.P.; Bevan, A.; Racine, E.B.; Shortridge, A.; et al. Package "Raster". Available online: https:/CRAN.R-project.org/package= raster (accessed on 19 October 2019).

54. Leutner, B.; Horning, N.; Schwalb-Willmann, J.; Hijmans, R.J. RStoolbox: Tools for Remote Sensing Data Analysis. Available online: https://rdrr.io/cran/RStoolbox/ (accessed on 19 October 2019).

55. Gottlicher, D.; Obregón, A.; Homeier, J.; Rollenbeck, R.; Nauss, T.; Bendix, J. Land-Cover Classification in the Andes of Southern Ecuador Using Landsat ETM+ Data as a Basis for SVAT Modelling. Int. J. Remote Sens. 2009, 30, 1867-1886. [CrossRef]

56. Ramirez-Gomez, S.O.I.; Brown, G.; Verweij, P.A.; Boot, R. Participatory Mapping to Identify Indigenous Community Use Zones: Implications for Conservation Planning in Southern Suriname. J. Nat. Conserv. 2016, 29, 69-78. [CrossRef]

57. Allpa. Las Comunidades Campesinas En La Región Junín; Allpa: Lima, Peru, 2009.

58. Comisión Técnica Regional Junín ZEE-CTRJ. Memoria Descriptiva Del Submodelo de Aptitud Urbano Industrial Del Departamento de Junín a Escala 1:100 000; CTRJ: Huancayo, Peru, 2015.

59. Comisión Técnica Regional Junín ZEE-CTRJ. Memoria Descriptiva Del Estudio Cultural Del Departamento de Junín a Escala 1:100 000; CTRJ: Huancayo, Peru, 2015.

60. Instituto Nacional de Estadística e Informática-INEI. Principales Indicadores. Available online: https: //www.inei.gob.pe/ (accessed on 30 July 2018).

61. Instituto Geofísico del Perú-IGP. Diagnóstico de La Cuenca Del Mantaro Bajo La Visión Del Cambio Climático, 1st ed.; Comisión Nacional del Ambiente-CONAM, Ed.; Fondo editorial del CONAM: Lima, Peru, 2005.

62. Instituto Geofísico del Perú-IGP. Eventos Meteorológicos Extremos (Sequías, Heladas, Lluvias Intensas) En El Valle Del Mantaro-Tomo I, 1st ed.; Villaverde Calderón, M., Ed.; Instituto Geofísico del Perú: Lima, Peru, 2012. [CrossRef]

63. Comisión Técnica Regional Junín ZEE-CTRJ. Memoria Descriptiva Del Estudio Geológico Del Departamento de Junín a Escala 1:100 000; CTRJ: Huancayo, Peru, 2015.

64. Bloomberg. Azulcocha Mining, S.A.: Private Company Information-Bloomberg. Available online: https://www.bloomberg.com/research/stocks/private/snapshot.asp?privcapId=104768226 (accessed on 30 August 2017).

65. Clean Technology. Estudio de Impacto Ambiental Unidad Económica Administrativa Azulcocha Tomo I; Clean Technology S.A.C.: Lima, Peru, 2007.

66. Barradas, S. Corihuarmi mine, Peru. Available online: http://www.miningweekly.com/article/corihuarmimine-peru-2013-08-30 (accessed on 30 August 2017).

67. Autoridad Nacional del Agua-ANA. Evaluación de Recursos Hídricos En La Cuenca de Mantaro; Autoridad Nacional del Agua: Lima, Peru, 2015.

68. Autoridad Nacional del Agua-ANA. Evaluación de Recursos Hidricos de Doce Cuencas Hidrográficas Del Perú; ANA: Lima, Peru, 2016.

69. Minera IRL. Corihuarmi Gold Mine. Available online: http://www.minera-irl.com/corihuarmi-3/ (accessed on 30 August 2017).

70. Rumbo Minero. Entérate de las nuevas modificaciones al proyecto Huacravilca en Junín. Available online: http://www.rumbominero.com/noticias/mineria/enterate-de-las-nuevas-modificaciones-al-proyectohuacravilca-en-junin/ (accessed on 30 August 2017).

71. Fresnillo Perú S.A.C. Informe Técnico Sustentatorio: Reubicación de Plataformas, Redimensionamiento de Accesos y Ampliación Del Cronograma Del Proyecto Huacravilca; Fresnillo Perú S.A.C.: Lima, Peru, 2017. 
72. Blache Snow Consulting. Primera Modificación de La Declaración de Impacto Ambiental: Proyecto de Exploración Huacravilca; Blache Snow Consulting: Lima, Peru, 2012.

73. Instituto Geológico Minero y Metalúrgico-INGEMMET. Geocatmin. Available online: http://geocatmin. ingemmet.gob.pe/geocatmin/ (accessed on 2 October 2018).

74. Ministerio del Ambiente-MINAM. Decreto Supremo $N^{\circ}$ 015-2015-MINAM Modifican Los Estándares Nacionales de Calidad Ambiental Para Agua y Establecen Disposiciones Complementarias Para Su Aplicación; El Peruano; MINAM: Lima, Peru, 2015; p. 3.

75. Ministerio del Ambiente-MINAM. Aprueban Estandares de Calidad Ambiental (ECA) Para Agua y Establecen Disposiciones Complementarias; El Peruano; MINAM: Lima, Peru, 2017; pp. 6-9.

76. Ayers, R.S.; Westcot, D.W. Water Quality for Agriculture; Food and Agriculture Organization of the United Nations: Rome, Italy, 1985.

77. Autoridad Nacional del Agua-ANA. Protocolo Nacional Para El Monitoreo de La Calidad de Los Recursos Hidricos Superficiales; ANA: Lima, Peru, 2016.

78. Wise, J.M. Tectono-Stratigraphic Histoy of the Huancayo Intermontane Basin, Central Peru. Bol. Soc. Geol. Peru 2007, 102, 63-72.

79. Mégard, F. Geología Del Cuadrángulo de Huancayo; Serv. Geol. y Minería: Lima, Peru, 1968.

80. Bech, J.; Duran, P.; Roca, N.; Poma, W.; Sánchez, I.; Roca-Pérez, L.; Boluda, R.; Barceló, J.; Poschenrieder, C. Accumulation of $\mathrm{Pb}$ and $\mathrm{Zn}$ in Bidens Triplinervia and Senecio Sp. Spontaneous Species from Mine Spoils in Peru and Their Potential Use in Phytoremediation. J. Geochem. Explor. 2012, 123, 109-113. [CrossRef]

81. Ministerio del Ambiente-MINAM. Guía Para El Muestreo de Suelos; MINAM: Lima, Peru, 2014.

82. Instituto Geológico Minero y Metalúrgico-INGEMMET. Cuadrángulos de Mala, Lunahuaná, Tupe, Conayca, Chincha, Tantará y Castrovirreyna Abarcan Parte de Los Departamentos de Lima, Huancavelica y Junin (Huancayo); INGEMMET: Lima, Peru, 1983.

83. Caballero Martín, V. Imperialismo y Campesinado, 1st ed.; Caballero Martín, V., Ed.; Instituto de Estudios Andinos: Lima, Peru, 1981.

84. Organismo de Evaluación y Fiscalización Ambiental-OEFA. Reporte Público Del Informe de Supervisión Directa $N^{\circ}$ 165-2014-OEFA/DS-MIN; OEFA: Lima, Peru, 2014.

85. Organismo de Evaluación y Fiscalización Ambiental-OEFA. Reporte Público Del Informe de Supervisión Directa $N^{\circ}$ 389-2013-OEFA/DS-MIN e Informe N 166-2014-OEFA/DS-MIN; OEFA: Lima, Peru, 2013; p. 6.

86. Jarvis, A.; Reuter, H.I.; Nelson, A.; Guevara, E. Hole-filled seamless SRTM data V4, International Centre for Tropical Agriculture (CIAT). Available online: http://srtm.csi.cgiar.org/ (accessed on 20 July 2018).

87. U.S. Geological Survey-USGS. EarthExplorer-Home. Available online: https://earthexplorer.usgs.gov/ (accessed on 5 February 2018).

88. Pimple, U.; Sitthi, A.; Simonetti, D.; Pungkul, S.; Leadprathom, K.; Chidthaisong, A. Topographic Correction of Landsat TM-5 and Landsat OLI-8 Imagery to Improve the Performance of Forest Classification in the Mountainous Terrain of Northeast Thailand. Sustainability 2017, 9, 258. [CrossRef]

89. Esri. World Imagery. Available online: http://www.arcgis.com/home/item.html?id= 10df2279f9684e4a9f6a7f08febac2a9 (accessed on 1 June 2018).

90. McHugh, M.L. Interrater Reliability: The Kappa Statistic. Biochem. Med. 2012, 22, 276-282. [CrossRef]

91. Organismo de Evaluación y Fiscalización Ambiental—OEFA. Reporte Público Del Informe N ${ }^{\circ}$ 352-2011-OEFA/DS; OEFA: Lima, Peru, 2014; p. 6.

92. Organismo de Evaluación y Fiscalización Ambiental-OEFA. Reporte Público Del Informe No 889-2012-OEFA/DS; OEFA: Lima, Peru, 2012; p. 6.

93. Organismo de Evaluación y Fiscalización Ambiental-OEFA. Reporte Público Del Informe $N^{\circ}$ 070-2014-OEFA/DS-MIN; OEFA: Lima, Peru, 2014; p. 8.

94. Ministerio del Ambiente-MINAM. Decreto Supremo-DS Nº 011-2017-MINAM; MINAM: Lima, Peru, 2017; p. 4.

95. Organismo de Evaluación y Fiscalización Ambiental—OEFA. Resolución Directoral N $N^{\circ}$ 491-2013-OEFA/DFSAI; OEFA: Lima, Peru, 2013; p. 24.

96. Hoogesteger, J.; Urteaga, P. Agua e Inequidad: Discursos, Políticas y Medios de Vida En La Región Andina, 1st ed.; Hoogesteger, J., Urteaga, P., Eds.; Instituto de Estudios Peruanos: Lima, Peru, 2013. 
97. Rodbell, D.; Delman, E.; Abbott, M.; Besonen, M.; Tapia, P. The Heavy Metal Contamination of Lake Junín National Reserve, Peru: An Unintended Consequence of the Juxtaposition of Hydroelectricity and Mining. GSA Today 2014, 24, 4-10. [CrossRef]

98. Martin, A.J.; McNee, J.J.; Pedersen, T.F. The Reactivity of Sediments Impacted Metal-Mining in Lago Junin, Peru. J. Geochem. Explor. 2001, 74, 175-187. [CrossRef]

99. Blacksmith Institute. Peru—La Oroya Lead Pollution. Available online: https://www.pureearth.org/project/ la-oroya-lead-pollution/ (accessed on 5 February 2019).

100. Ng, J.C.; Wang, J.; Shraim, A. A Global Health Problem Caused by Arsenic from Natural Sources. Chemosphere 2003, 52, 1353-1359. [CrossRef]

101. Flora, S.J.S. Arsenic: Chemistry, Occurrence, and Exposure. In Handbook of Arsenic Toxicology; Flora, S.J.S., Ed.; Elsevier Inc.: London, UK, 2015; pp. 1-49. [CrossRef]

102. Levi Rendón, C. Estudio Del Yacimiento Minero de Cercapuquio; Universidad Nacional de Ingeniería: Lima, Peru, 1960.

103. World Health Organisation-WHO. Health Risks of Heavy Metals from Long-Range Transboundary Air Poluution; WHO: Copenhagen, Denmark, 2007; ISBN 9789289071796.

104. Kabata-Pendias, A.; Pendias, H. Trace Elements in Soils and Plants, 3rd ed.; Kabata-Pendias, A., Pendias, H., Eds.; CRP Press LLC: London, UK, 2001.

105. Shahid, M.; Shamshad, S.; Rafiq, M.; Khalid, S.; Bibi, I.; Niazi, N.K.; Dumat, C.; Rashid, M.I. Chromium Speciation, Bioavailability, Uptake, Toxicity and Detoxification in Soil-Plant System: A Review. Chemosphere 2017, 178, 513-533. [CrossRef]

106. Peralta-Videa, J.R.; Lopez, M.L.; Narayan, M.; Saupe, G.; Gardea-Torresdey, J. The Biochemistry of Environmental Heavy Metal Uptake by Plants: Implications for the Food Chain. Int. J. Biochem. Cell Biol. 2009, 41, 1665-1677. [CrossRef]

107. Razo, I.; Carrizales, L.; Castro, J.; Díaz-Barriga, F.; Monroy, M. Arsenic and Heavy Metal Pollution of Soil, Water and Sediments in a Semi-Arid Climate Mining Area in Mexico. Water Air Soil Pollut. 2004, 152, 129-152. [CrossRef]

108. Cotler, J. Clases, Estado y Nación En El Perú, 3rd ed.; Cotler, J., Ed.; Instituto de Estudios Peruanos: Lima, Peru, 2016.

109. Neumann, P. Toxic Talk and Collective (In)Action in a Company Town: The Case of La Oroya, Peru. Soc. Probl. 2016, 63, 431-446. [CrossRef]

110. Martínez Alier, J.; Roca Jusmet, J. Economía Ecológica y Política Ambiental, 3rd ed.; Fondo de Cultura Económica-FCE: Mexico City, Mexico, 2015.

111. Cooke, C.A.; Abbott, M.B. A Paleolimnological Perspective on Industrial-Era Metal Pollution in the Central Andes, Peru. Sci. Total Environ. 2008, 393, 262-272. [CrossRef] [PubMed]

112. Abanto Kcomt, C. Segundo Informe Sobre Evolución de La Calidad de Aire En La Oroya; Asociación Civil Labor: Lima, Peru, 2007.

113. Bury, J. Livelihoods, Mining and Peasant Protests in the Peruvian Andes. J. Lat. Am. Geogr. 2002, 1, 1-19. [CrossRef]

114. Prado Fernández, J.M.; Manzanares Cáceres, D.; Velázquez Díaz, F.; Taya Acosta, E. Agua, Minería Y Comunidades Campesinas En La Región Tacna Water, Mining and Rural Communities in the Región Tacna. Cienc. Desarro. 2013, 13, 73-80.

115. Conde, M. Resistance to Mining: A Review. Ecol. Econ. 2017, 132, 80-90. [CrossRef]

116. Warnaars, X.S. Why Be Poor When We Can Be Rich? Constructing Responsible Mining in El Pangui, Ecuador. Resour. Policy 2012, 37, 223-232. [CrossRef]

117. Ahlers, R. Fixing and Nixing: The Politics of Water Privatization. Rev. Radic. Political Econ. 2010, 42, $213-230$. [CrossRef]

(C) 2019 by the authors. Licensee MDPI, Basel, Switzerland. This article is an open access article distributed under the terms and conditions of the Creative Commons Attribution (CC BY) license (http://creativecommons.org/licenses/by/4.0/). 